The Canadian Mineralogist

Vol. 43, pp. 1959-1992 (2005)

\title{
MINERALS ARE NOT JUST CHEMICAL COMPOUNDS*
}

\author{
IAN PARSONS ${ }^{\S}$
}

Grant Institute of Earth Science, University of Edinburgh, West Mains Road, Edinburgh, EH9 3JW, United Kingdom

\section{MARTIN R. LEE}

Department of Geographical and Earth Sciences, University of Glasgow, Lilybank Gardens, Glasgow, G12 8QQ, United Kingdom

\begin{abstract}
Mineral grains are not just chemical compounds; they possess microtexture. The properties of crystallographically nearperfect "gem-quality" alkali feldspar crystals are contrasted here with those of ordinary, "garden-variety" specimens, exemplified by perthitic phenocrysts from the granite at Shap, northern England. These are representative of common alkali feldspars in the crust. Two well-studied gem-quality materials (Madagascar orthoclase and Eifel sanidine) vary at the source in microtextural and other properties. Some crystals of Eifel sanidine exhibit much more rapid $\mathrm{Si}-\mathrm{Al}$ ordering than ordinary feldspars, probably because of the presence of a hydrogen species. The complex microtextures of two feldspars from pegmatites that have been used in studies of dissolution rate, Perth perthite and Keystone microcline, are described and compared with textures in the Shap feldspars. Microtextures, in particular misfit dislocations on regular exsolution-lamellae of albite, are crucially important in chemical dissolution and mechanical degradation during natural weathering in acid peat soils at Shap. In contrast, during laboratory dissolution-rate experiments carried out far from equilibrium, natural defects are less important than edges and steps produced during the grinding of the samples. Diagenetic replacement-type reactions in an overlying conglomerate at Shap are also strongly sensitive to microtexture. In arkosic sandstones in the Jurassic Fulmar Formation of the central North Sea, the detrital alkali feldspar inventory has been subject to microtextural winnowing, with relatively defect-free varieties of alkali feldspar being relatively more abundant than would be expected from the distribution of rock types known in the North Sea catchment.
\end{abstract}

Keywords: mineral microtexture, alkali feldspar, exsolution, dislocations, dissolution-reprecipitation, dissolution, replacement, gem-quality minerals, weathering, diagenesis.

\section{SOMMAIRE}

Les grains de minéraux ne sont pas simplement des composés chimiques; ils possèdent une microtexture. Les propriétés de cristaux gemmes de feldspath alcalin sont ici comparées avec celles de cristaux perthitiques tout-à-fait ordinaires provenant du granite de Shap, au nord de l'Angleterre. Ces derniers seraient représentatifs des feldspaths communs de la croûte. Deux matériaux gemmes bien étudiés, l'orthose du Madagascar et la sanidine d'Eifel, sont pris de populations variables à la source dans leur microtexture et leurs propriétés. Certains cristaux provenant de l'Eifel font preuve d'une mise en ordre Si-Al beaucoup plus rapide que ces feldspaths ordinaires, probablement à cause d'une espèce hydrogénée. Les microtextures complexes de deux feldspaths provenant de pegmatites et utilisés dans les études du taux de dissolution, la perthite de Perth et le microcline de Keystone, sont décrites et comparées aux textures des feldspaths provenant de Shap. Ces microtextures, en particulier les dislocations dues au décalage le long des lamelles d'exsolution d'albite, sont très importantes dans la dissolution chimique et la dégradation méchanique au cours du lessivage naturel dans les sols acides des tourbières à Shap. En revanche, au cours des expériences de laboratoire visant à caractériser la dissolution à des conditions loin de l'équilibre, les défauts naturels semblent moins importants que le dommage créé lors de la préparation des échantillons. Les réactions diagénétiques de type remplacement dans un conglomérat reposant sur le granite à Shap dépendent aussi de la microtexture. Dans les grès arkosiques jurassiques de la Formation de Fulmar, dans le centre de la mer du Nord, le bilan des grains détritiques de feldspath alcalin a été sujet à un vannage microtextural, les variétés de feldspath alcalin relativement dépourvues de défauts étant relativement plus abondantes que ce qui est attendu selon la distribution des roches connues dans le bassin de drainage de la mer du Nord.

(Traduit par la Rédaction)

Mots-clés: microtexture minérale, feldspath alcalin, exsolution, dislocations, dissolution-reprécipitation, dissolution, remplacement, minéraux gemmes, lessivage, diagenèse.

§ E-mail address: ian.parsons@ed.ac.uk

* Plenary lecture to mark the $50^{\text {th }}$ anniversary of the Mineralogical Association of Canada. 


\section{INTRODUCTION}

The idea that minerals are natural substances with generic physical properties can be traced back at least to Nicolas Steno's 1669 observations of the constancy of angles in crystals. By the latter half of the $19^{\text {th }}$ century, most of the important mineral species had been established on the basis of their physical rather than chemical properties. Even today, elementary mineralogy courses usually start by stressing the perfection of crystals and the way physical properties can be used to place minerals in taxonomic pigeonholes. To a first approximation, it is a concept that has stood the test of time and has served us well. But it can be pushed too far. There are geologically important areas, especially at the geochemistry-mineralogy interface, where the imperfections of crystals are crucial to their behavior. Minerals are not just chemical compounds whose properties can be applied generically like laboratory reagents.

The realization that many mineral species are chemically complex, with large ranges of variation in major elements, came later, as analytical techniques evolved during the $20^{\text {th }}$ century. Today, with an extraordinary range of analytical methods available, the concept that minerals have fixed chemical compositions is long dead. Curiously though, the notion that physical properties can be applied generically across mineral species is still very firmly entrenched. For example, in the field of thermochronology, it is often taken as read that diffusion-rate coefficients and mechanisms (and hence the so-called "closure temperature") can be freely extrapolated from a particular experimental material to all other examples of the mineral. In the present paper, we explore this theme by describing the properties, some rather strange, of examples of crystallographically nearperfect "gem-quality" alkali feldspars, and comparing them with ordinary "garden-variety" examples of the species. We look at the down-temperature evolution of defect microtextures in alkali feldspars during cooling from temperatures of igneous growth and show that these features are ultimately crucial to dissolution during weathering and to reactions in confined spaces in soils and sedimentary rocks.

"Gem-quality" crystals of striking beauty and perfection are often used to obtain fundamental physical properties of mineral species. In many cases, they have been carefully characterized and shown to be devoid of gross chemical and physical heterogeneities such as chemical zoning, solid and liquid inclusions, exsolution features and twins, and to have very low concentrations of dislocations and point defects, all features that can be collectively described as "microtexture". Some popular experimental materials, such as San Carlos olivine and Amelia albite, have become almost household words. Experiments using crystallographically perfect material must be the starting point for in-depth understanding of any physical property of a mineral, but most mineralogists are well aware that such crystals can be very different in some of their properties from "garden-variety" examples of the same species. Some experimental starting materials with no pretentions to gem quality have been used to provide dissolution-rate data that were intended to be applied generically. We describe specific microtextures in two well-known examples of feldspars taken from pegmatites used for such studies, and discuss the realities of laboratory dissolution in the case of an alkali feldspar from a granite, which we consider to be much closer to a "typical" crustal alkali feldspar.

Much of this paper is based on an intensive study of alkali feldspar phenocrysts from the porphyritic Lower Devonian granite, at Shap, northern England (Lee \& Parsons 1995, Lee et al. 1995, 1998, Lee \& Parsons 1997a, b, 1998). "Fresh" samples can readily be obtained from a large quarry, and weathered samples can be studied on glacially scoured exposures and in peat soils. Fragments of phenocrysts can be recognized in an overlying Lower Carboniferous conglomerate, and the effect of diagenetic processes distinguished. We can therefore trace the behavior of the crystals from igneous growth at $\sim 750^{\circ} \mathrm{C}$ to post-glacial weathering at presentday or cooler surface temperatures, and also during diagenetic processes at $70-125^{\circ} \mathrm{C}$. In a final section, we visit a North Sea petroleum reservoir and show how the dissolution of detrital feldspars there depends as much on microtexture as on chemical composition.

The abundance and diversity of defect microtextures in crystals of ordinary alkali feldspar from plutonic rocks are exceptional and probably exceed those of any other common group of minerals. We say "probably" because the microtextures of alkali feldspars have been more intensively studied than those of any other species. Nevertheless, the principles we describe below will apply, albeit in less diverse ways, to other garden-variety minerals. In general, microtextural data are simply not available for ordinary grains of many common rock-forming minerals in geological contexts. We hope that this review may stimulate others to explore what is still a largely untraveled world.

\section{Terminology and Phase Relationships IN THE ALKALI FELDSPARS}

Before we develop our main theme, it may be helpful for some readers if we introduce some terminology and summarize briefly current understanding of phase equilibria and phase behavior in alkali feldspars, concentrating on features relevant to garden-variety alkali feldspars from granitic rocks. There is inevitably some oversimplification. Rigorous treatments are given by Smith \& Brown (1988) and Brown \& Parsons (1989). The different microtextural regions that can be found in a typical $100 \mu \mathrm{m}$ cleavage fragment of a phenocryst from a sample of quarried Shap granite are summarized on Figure 1. Compositions of its constituent parts are given in Table 1, from Lee \& Parsons (1997a, b). 


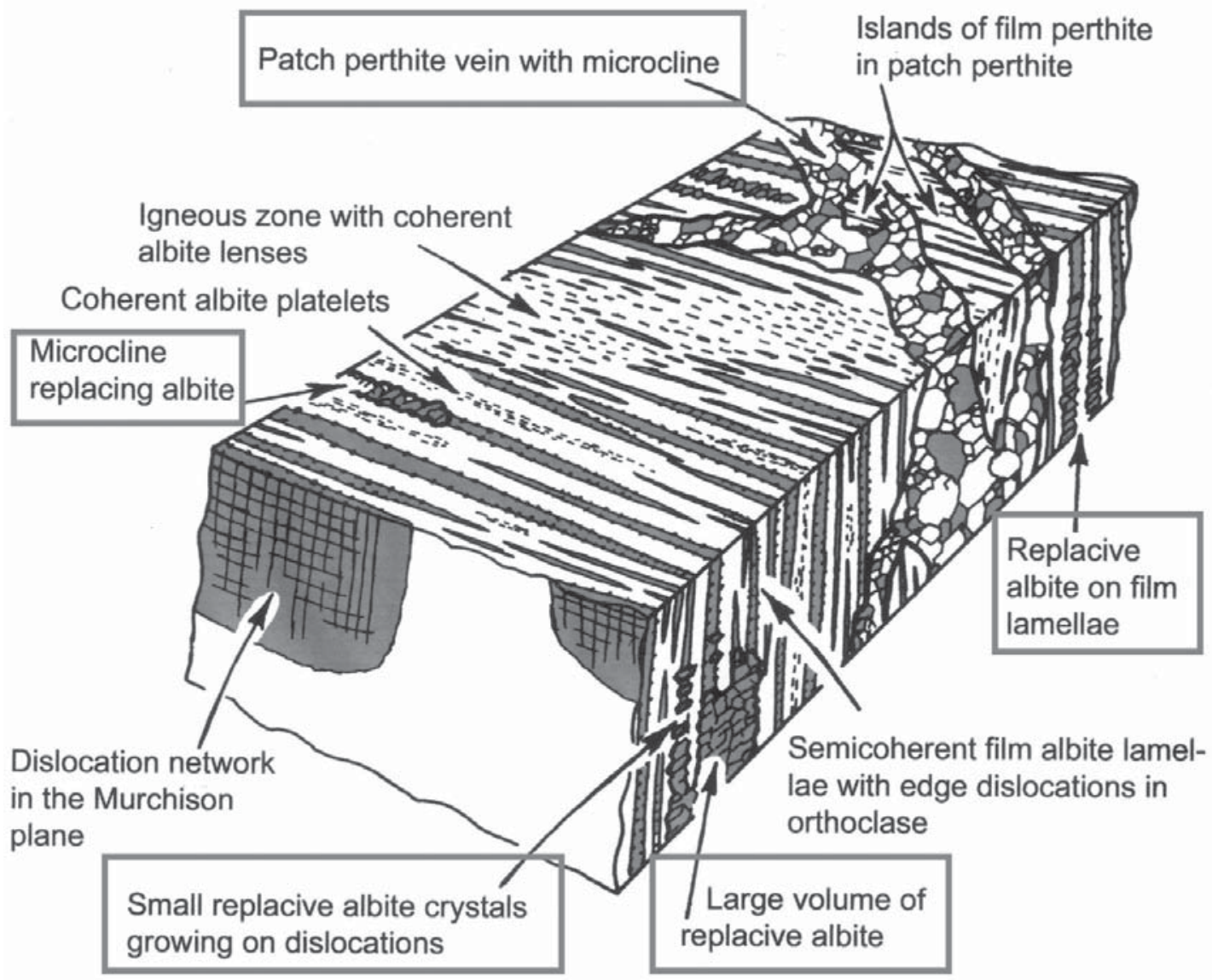

FIG. 1. Sketch of a typical 100- $\mu$ m-long cleavage fragment of an alkali feldspar phenocryst from the Shap granite, showing the microtextural elements. Albite is grey, orthoclase and microcline are white. The front surface is the Murchison plane, between

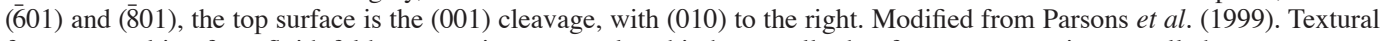
features resulting from fluid-feldspar reactions are enclosed in boxes; all other features are strain-controlled.

Figure 2 is a slightly modernized version of Figure 8 in Brown \& Parsons (1989). The curves and fields in the conventional phase-diagram (a) are based on the combined efforts of many experimentalists, and the curves in the behavior diagram (b) are a combination of experimental work and observations of relationships in alkali feldspars from rocks. The review by Brown \& Parsons should be consulted for details.

\section{Stable (strain-free) phase relationships}

Figure $2 \mathrm{a}$ is a normal phase-diagram showing supposed thermodynamically stable phase-relationships in the binary alkali feldspar system in which the components are albite $\left(\mathrm{Ab}, \mathrm{NaAlSi}_{3} \mathrm{O}_{8}\right)$ and "orthoclase" (Or, $\mathrm{KAlSi}_{3} \mathrm{O}_{8}$ ). The strain-free solvus curve depicts the compositions of pairs of $\mathrm{Ab}$ - and Or-rich feldspar phases coexisting in equilibrium that have physically discontinuous $\mathrm{Si}-\mathrm{Al}-\mathrm{O}$ frameworks. The curve shown is a composite constructed from solvi obtained by Müller (1971) for feldspars with different degrees of $\mathrm{Si}-\mathrm{Al}$ order in the framework (see next paragraph). The two feldspar phases may exist as separate sets of crystals or as discontinuous (i.e., incoherent or "strain-free") intergrowths within single feldspar crystals known generically as perthite. Incoherent perthitic intergrowths are irregular in shape and form by exsolution (also called unmixing) involving dissolution-reprecipitation reactions in an aqueous fluid, or by replacement. In our example from Shap (Fig. 1), incoherent intergrowths are labeled in boxes. At temperatures $(T)$ above the solvus (hypersolvus crystallization), a single alkali feldspar phase, either monoclinic sanidine or triclinic high albite (HA), grows (from magma, or during high- 
grade metamorphism). At $T$ below the strain-free solvus (subsolvus crystallization), two feldspar phases grow, as physically separate crystals of sodic plagioclase and alkali feldspar, with bulk compositions defined by the solvus. Simultaneous growth of two feldspars is the usual situation in granitic rocks such as the Shap granite, but the effect of the third common feldspar component anorthite $\left(\mathrm{CaAl}_{2} \mathrm{Si}_{2} \mathrm{O}_{8}, \mathrm{An}\right)$ is important because it has a strong effect on solvus $T$. Strictly speaking, all feldspars are ternary solid-solutions, and phase compositions should be depicted by tie-lines in the ternary system $\mathrm{Ab}-\mathrm{Or}-\mathrm{An}$. The effect of An on the solvus curves projected onto $\mathrm{Ab}-\mathrm{Or}$ join is poorly known, but 1 mol.\% An is likely to increase exsolution temperatures by at least $100^{\circ} \mathrm{C}$ on the steep solvus limbs. Thus in a typical "subsolvus" granite like Shap, in which the bulk compositions of the alkali feldspars is $\sim \mathrm{Ab}_{29} \mathrm{Or}_{70} \mathrm{An}_{1}$, the feldspars crystallized at $T$ between $\sim 700$ and $800^{\circ} \mathrm{C}$, depending on the degree of $\mathrm{Si}-\mathrm{Al}$ order at the time of growth (Lee \& Parsons 1997a), well above the An-free solvus shown (Fig. 2a).

As well as unmixing of the large monovalent cations, ordering of much smaller $\mathrm{Al}^{3+}$ and $\mathrm{Si}^{4+}$ cations in the framework also occurs in feldspars. Order-disorder of $\mathrm{Si}$ and $\mathrm{Al}$ can be understood by reference to the feldspar structure illustrated in Figure 3. Every point where lines join on the drawing is the center of a $\mathrm{Si}-\mathrm{O}$ or $\mathrm{Al}-\mathrm{O}$ tetrahedron (the oxygen ions are not shown). In alkali feldspars, the $\mathrm{Si}: \mathrm{Al}$ ratio is $3: 1$. At high $T$, the $\mathrm{Si}$ and $\mathrm{Al}$ ions are arranged randomly (are disordered) over four equivalent tetrahedral sites labeled by convention $\mathrm{T}_{1}(0)$, $\mathrm{T}_{1}(\mathrm{~m}), \mathrm{T}_{2}(0)$ and $\mathrm{T}_{2}(\mathrm{~m})$. Sanidine is monoclinic with mirror symmetry in the $a-c$ plane and a two-fold axis parallel to $b$. High sanidine is almost fully disordered, but orders during slow cooling to produce partially ordered low sanidine (LS on Fig. 2a) by diffusion of Al from $\mathrm{T}_{2}$ to $\mathrm{T}_{1}$ sites. This ordering is usually described, following Thompson (1969), by an order parameter $Z$ $=\left(t_{1} 0+t_{1} m\right)-\left(t_{2} 0+t_{2} m\right)$, where $t$ is the fraction of the site occupied by Al. In fully disordered high sanidine, $\mathrm{t}$ is equal to 0.25 ; in hypothetical low sanidine with complete $Z$ order, $\mathrm{t}_{1}$ is equal to 0.5 . The $Z$ parameter can be estimated from $2 V_{x}$, provided the feldspar's composition is known (Su et al. 1986). High sanidine has its optic axial plane (OAP) parallel to (010); in low sanidine, the OAP is normal to (010).

Further ordering leads to development of the triclinic polymorph microcline, usually easily recognized in thin section by its distinctive "tartan" twinning. The monoclinic symmetry is broken, and the structure becomes triclinic because $\mathrm{Al}$ diffuses into $\mathrm{T}_{1}(0)$ sites (shown by the black atoms in Fig. 3). Although the structure in Figure 3 is drawn with monoclinic symmetry, in reality this ordered framework would give rise to a triclinic cell by slight relative twisting of the tetrahedra. This symmetry-breaking ordering is described by the order parameter $Y$ equal to $\mathrm{t}_{1} 0-\mathrm{t}_{1} \mathrm{~m}$; in fully ordered low microcline (LM on Fig. $2 \mathrm{a}$ ), $\mathrm{t}_{1} 0$ is equal to 1 . The horizontal line beneath "LS" on Figure $2 \mathrm{a}$ is a monoclinic-triclinic phase transition. In the orange band, the $\alpha$ and $\gamma$ cell angles depart progressively from $90^{\circ}$ as $Y$ ordering proceeds, and the order parameter can be obtained from the cell angles, most simply from the splitting of X-ray-diffraction peaks. There is uncertainty as to whether the band on the right-hand side of Figure 2a represents a stable field of existence for intermediate microcline. Carpenter \& Salje (1994) considered that intermediate microcline is not a stable phase, whereas Brown \& Parsons (1989) suggest that intermediate microcline is a stable phase over a limited range of $T$. Microcline has yet to be convincingly synthesized.

A steeply inclined phase-boundary separates the large field of monoclinic sanidine from that of triclinic high albite (HA). This symmetry change does not involve diffusion of framework ions, but is caused by tilting of $\mathrm{Si}-\mathrm{Al}-\mathrm{O}$ tetrahedra. It is called a shearing or displacive phase-transition, and unlike the orderdisorder transformation, which is relatively slow, it is instantaneous and unquenchable. Because high albite is triclinic at the onset of ordering, diffusion of $\mathrm{Al}$ into $\mathrm{T}_{1}(0)$ from $\mathrm{T}_{2}$ and $\mathrm{T}_{1}(\mathrm{~m})$ sites starts at high $T$ and takes place by a one-step process. For reasons that will be made clear in the following section, low albite can be synthesized relatively quickly and was first made by Martin (1969).

\section{Coherent phase behavior}

The stable phase-equilibria of Figure $2 \mathrm{a}$ are inadequate to describe the microtextures and phase relationships we see in garden-variety alkali feldspars like our example from Shap (Fig. 1). We need a diagram (Fig. 2b) that shows the intracrystal phase-behavior of alkali feldspars where the $\mathrm{Si}-\mathrm{Al}-\mathrm{O}$ framework remains continuous (coherent) or nearly so (semicoherent) during both exsolution and ordering transformations. An alkali feldspar like Shap grows on the strain-free solvus as a homogeneous sanidine, together with plagioclase. If stable equilibrium was maintained during cooling, both phases should exchange $\mathrm{Na}$ and $\mathrm{K}$ and maintain compositions on the strain-free solvus. This rarely, perhaps never, happens. In practice, the homogeneous feldspars cool until they intersect a second solvus curve, the coherent solvus (Fig. 2b). Alkali ions diffuse through the coherent framework, and phase compositions define a metastable solvus that plots inside the strain-free solvus. The phases are no longer independent, as they are in a stable phase-diagram, and their behavior depends on the bulk composition and thermal history of each crystal. Strictly speaking, there is a different solvus for each bulk composition. The coherent solvi differ from the strain-free solvus because of the contribution to the total free energy of coherency strain energy. This elastic strain arises because of structural distortions required 
TABLE I. COMPOSITION OF ALKALI FELDSPARS FROM THE SHAP GRANITE AND FROM PEGMATITES

\begin{tabular}{|c|c|c|c|}
\hline & $\mathrm{Ab}$ & Or & An \\
\hline \multicolumn{4}{|c|}{ Phenocrysts from the Shap granite (Lee \& Parsons $1997 \mathrm{a}, \mathrm{b}$ ) } \\
\hline Lamellar microperthite (bulk) & 27.6 & 71.8 & 0.6 \\
\hline Cryptoperthitic zone (bulk) & 30.5 & 68.6 & 1.0 \\
\hline Orthoclase and microcline in patch perthite vein & 9.4 & 90.4 & 0.3 \\
\hline Albite in patch perthite vein & 89.8 & 1.5 & 8.7 \\
\hline Pure replacive albite & 99.1 & 0.7 & 0.2 \\
\hline
\end{tabular}

\begin{tabular}{lrrr}
\multicolumn{3}{c}{ Perth perthite } \\
\\
Bulk powder (l Ioldren \& Speyer 1987) & 42.0 & 57.4 & \\
* Microctine including eryptoperthitic albite & 7.2 & 92.8 & 0.6 \\
* Albite macroperthite veins & 99.2 & 0.6 & 0.2 \\
\hline
\end{tabular}

Keystone microcline

$\begin{array}{lrrr}\text { Bulk powder (Holdren \& Speyer 1987) } & 20.7 & 78.3 & 1.0 \\ \text { * Microctinc including cryptoperthitic albitc } & 5.7 & 94.3 & 0.0 \\ \text { * Albite macroperthite veins } & 99.6 & 0.4 & 0.0\end{array}$

* Results of new electron-microprobe analyses made using a rastered beam, and undertaken for this study. Compositions are quoted in mol.\%.

to accommodate the difference in cell dimensions of the Ab- and Or-rich phases. Brown \& Parsons (1993) estimated that in fine-scale perthites of median composition (cryptoperthites and cryptomesoperthites, Fig. 2b), stored elastic coherency strain energy might be $\sim 2.5-4$ $\mathrm{kJ} \mathrm{mol}^{-1}$. Exsolution lamellae in coherent intergrowths adopt orientations that minimize coherency-strain energy. In feldspars from syenites (which usually have compositions around $\mathrm{Ab}_{60} \mathrm{Or}_{40}$ : Brown et al. 1983, Brown \& Parsons 1984a), this leads to complex braid and zig-zag intergrowths, but in more Or-rich feldspars from subsolvus granites (usually $\mathrm{Ab}_{30} \mathrm{Or}_{70}-\mathrm{Ab}_{10} \mathrm{Or}_{90}$ ) straight film perthites (Fig. 4) form. As film perthites cool and lamellae coarsen, they develop spaced misfitinduced dislocations (Figs. 1, 4, 5, and see below) to relieve coherency strains and become semicoherent. In coherent and semicoherent intergrowths, phase compositions, the orientation of exsolution lamellae, twinning and twin-domain microtextures related to phase transitions, development of dislocations, and framework order are all coupled and can be represented only on a behavior diagram (Fig. 2b). The orientation and periodicity of the different microtextural elements are the product of crystallographic self-organization in which atoms diffuse down chemical potential gradients dominated (constrained) by elastic strain energy.

As well as its role in exsolution, coherency leads to strong coupling between the ability to order and coherency stresses and strains (Fig. 2b). In low sanidine, at the monoclinic-triclinic phase transition in the straight film perthites characteristic of alkali feldspars from subsolvus granites, a distinctive "tweed" microtexture develops during ordering (Fig. 5). "Tweed" is the defining characteristic of orthoclase, sensu stricto (Eggleton \& Buseck 1980a). The microtexture forms because in partly ordered low sanidine, in which $\mathrm{Al}$ has been concentrated in $\mathrm{T}_{1}$ tetrahedral sites, related by mirror symmetry, there are, at the inception of $Y$ ordering, two undifferentiated $\mathrm{T}_{1}$ sites into which $\mathrm{Al}$ may move to produce triclinic microcline. On Figure 3, there is a chain of $\mathrm{Al}$ ions in $\mathrm{T}_{1}(0)$ sites sloping from top left to bottom right. An alternative drawing would show this chain sloping from top right to bottom left. The cooling crystal is confronted with a "choice" as to which of the hitherto undifferentiated $\mathrm{T}_{1}$ sites will become $\mathrm{T}_{1}(0)$. Alternating "left" and "right" coherent domains (the tweed microtexture) develop over a distance of a few unit cells, contributing elastic coherency strainenergy of $\sim 2-3 \mathrm{~kJ} \mathrm{~mol}^{-1}$ (Brown \& Parsons 1993). The overall symmetry remains monoclinic to $\mathrm{X}$-rays or to light optics. Further ordering and domain enlargement are inhibited because both lead to increase in coherency strains. Tweed orthoclase becomes stranded and unable to order further to produce microcline. Thus, orthoclase is a metastable phase, which should not appear on a conventional phase-diagram (Fig. 2a), although it has an important place on our behavior diagram (Fig. 2b). It remains stranded with its tweed microtexture over immense periods of geological time. Intermediate microcline appears in mesoperthites on Figure $2 b$ because it occurs in Ab-rich alkali feldspars with zig-zag or braid cryptoperthitic intergrowths in which coherency strains involving the already triclinic albite phase define the orientation of the microtexture, and the Or-rich phase is not confronted with a "choice" (Brown \& Parsons 1984a).

\section{Unzipping reactions}

Coherency strains and related dislocations are keys to the reactivity of alkali feldspars in aqueous fluids during the cooling of igneous and metamorphic rocks (Worden et al. 1990, Brown \& Parsons 1993). Dissolution-reprecipitation reactions play an essential role in marked coarsening of perthite (Fig. 6) and in facilitating the transformation of orthoclase to microcline (Waldron et al. 1993). Such reactions release elastic strain in coherent perthites and in tweed orthoclase, and have been collectively called "unzipping reactions" (Brown \& Parsons 1993). Perthite coarsened by this process has been subject to deuteric coarsening and can be called deuteric perthite (Parsons \& Brown 1984). Deuteric perthite is largely strain-free, irregular in shape (Fig. 6 ) and up to $10^{3}$ times coarser than strain-controlled perthite. During the coarsening, phase compositions move from the coherent solvus and are defined by the strain-free solvus (Fig. 2a). In transmission electron microscope (TEM) images, they prove to be profoundly recrystallized to sub- $\mu \mathrm{m}$-scale mosaics of albite and K- 

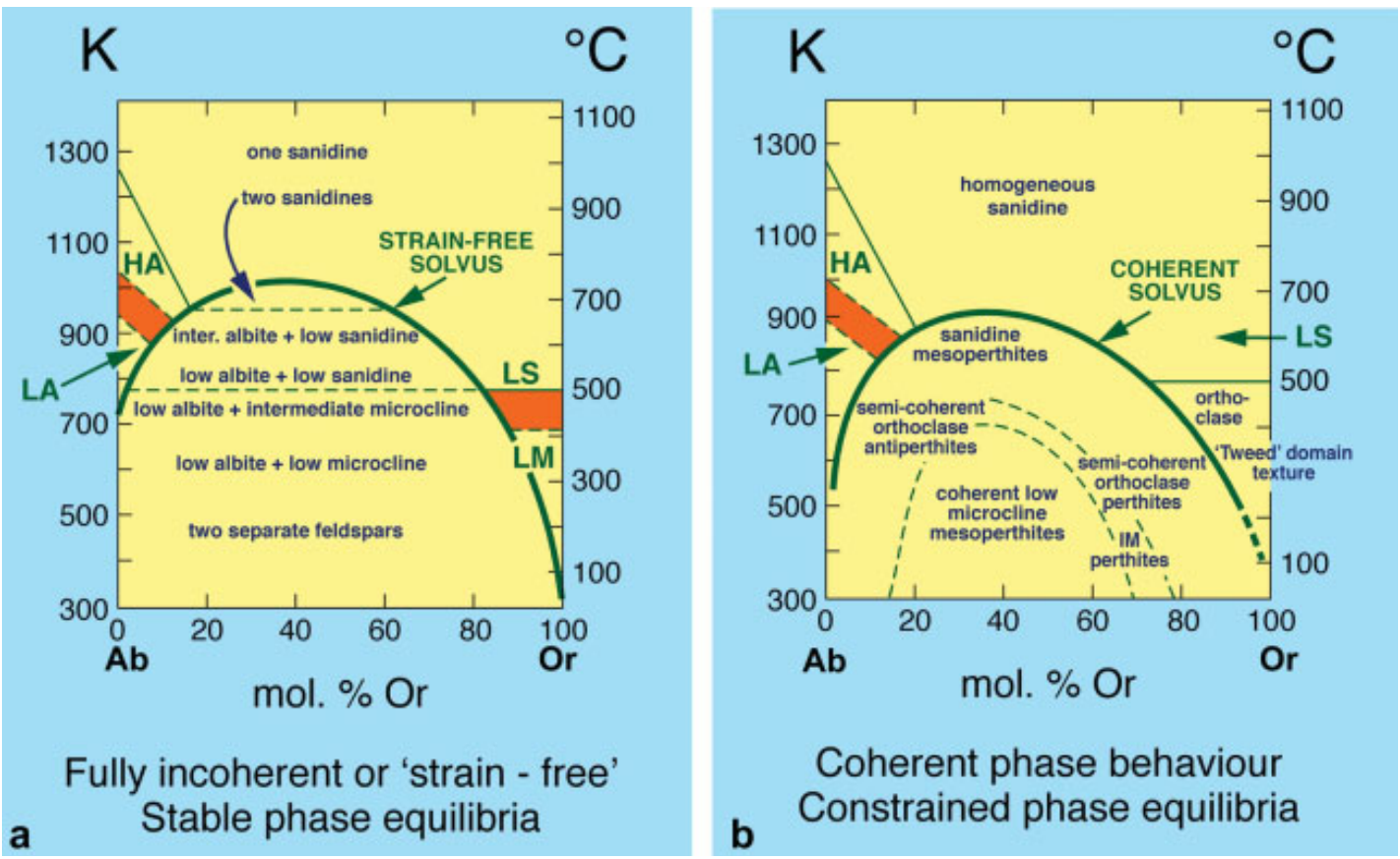

FIG. 2. (a) Stable equilibrium phase-diagram for binary alkali feldspars. The solvus is the strain-free solvus for an equilibrium degree of $\mathrm{Si}-\mathrm{Al}$ order. Where two feldspars coexist on the solvus, they do so without interaction except reciprocal $\mathrm{Na}-\mathrm{K}$ exchange. Phase transitions in the two phases are not coupled. HA: high albite. LA: low albite. LS: low sanidine. LM: low microcline. (b) Behavior diagram. The solvus is the coherent solvus for frameworks with equilibrium $\mathrm{Si}-\mathrm{Al}$ order. Phase transitions in the two phases are coupled by coherency strain. Strictly speaking, the position of the solvus varies with bulk composition. See Brown \& Parsons (1989) for details of the construction of these diagrams. Note that all natural feldspars are ternary solid-solutions that include the An component; projected solvus temperatures will be higher as a result. The orange bands indicate the $T$ range in which most of the $Y$-ordering occurs. This is unlikely to be significantly affected by small An contents.

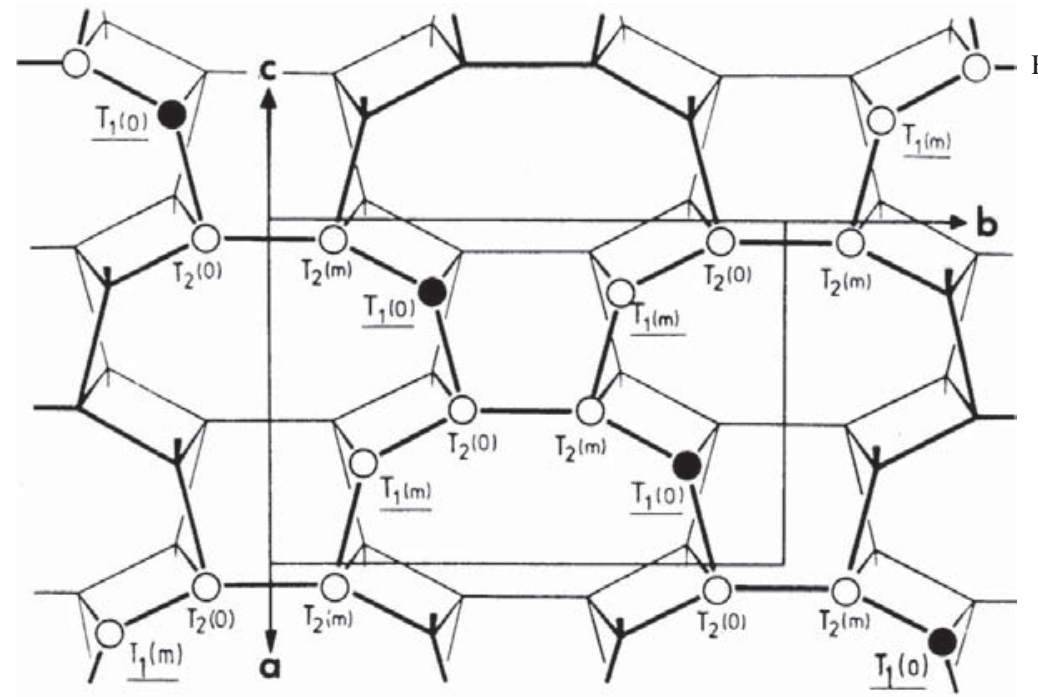

FIG. 3. Idealized projection of the feldspar structure onto $(001)$ (Laves 1960). All points where lines join are the centers of $\mathrm{Si}-\mathrm{O}$ or Al-O tetrahedra ( $\mathrm{T}$ sites). The structure is idealized, with monoclinic symmetry. In a fully disordered structure, $\mathrm{Al}^{3+}$ (solid circles) and $\mathrm{Si}^{4+}$ (open circles) would be distributed randomly on $\mathrm{T}$ sites. However, the structure shown is fully ordered, with all $\mathrm{Al}^{3+}$ on a site called $\mathrm{T}_{1}(0)$, forming a chain in the [110] direction. The equivalent $[1 \overline{1} 0]$ chain contains no Al, and the mirror symmetry is lost. In a real structure, ordering would be accompanied by relative twisting of the tetrahedra, and the unit cell would be triclinic. 


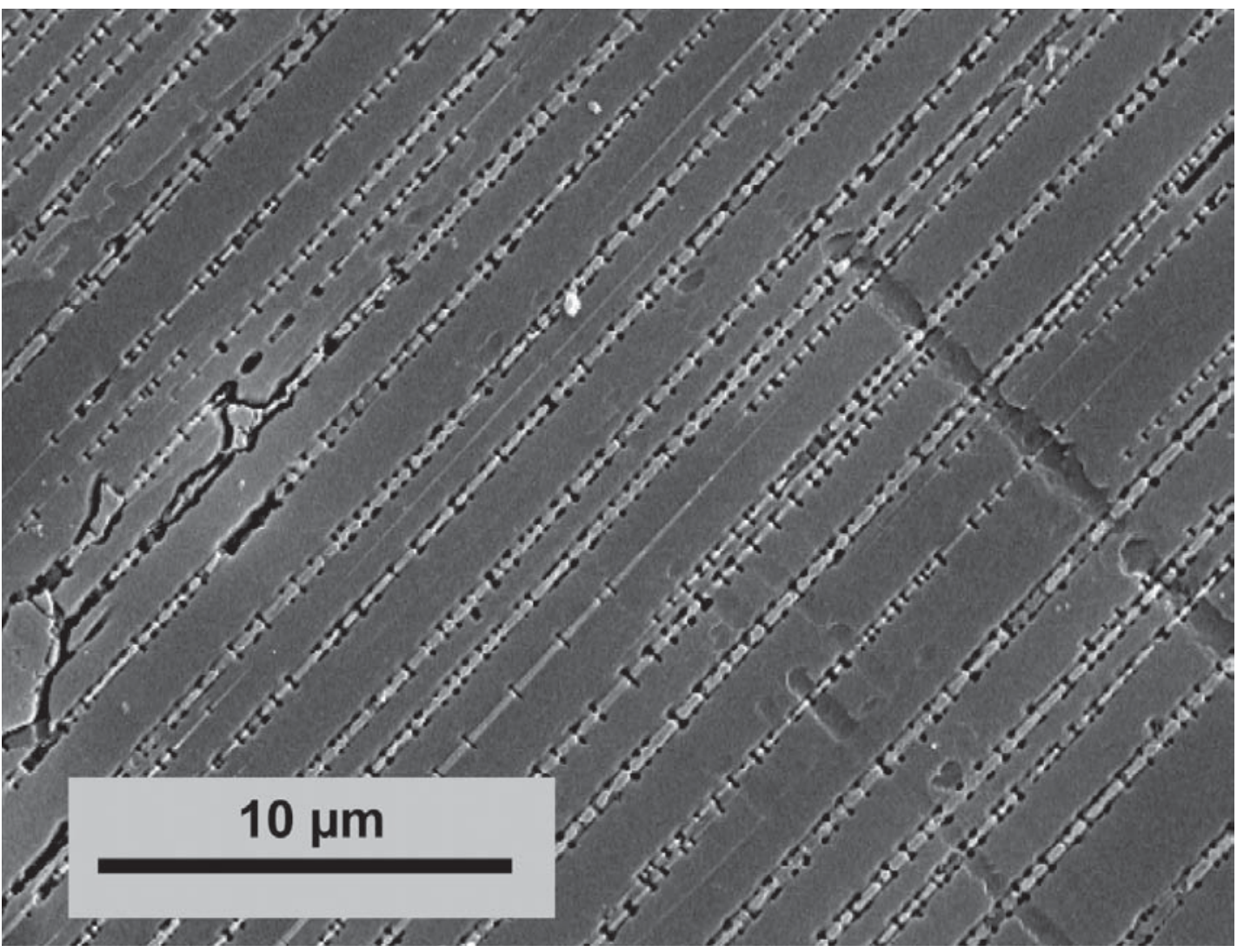

FIG. 4. Secondary electron (SE) image (SEM) of a (001) cleavage surface of a fragment of an alkali feldspar phenocryst from the Shap granite (see Figs. 1 and 7d) that has been etched briefly in HF vapor. Semicoherent albite lamellae in the Murchison plane are decorated with paired etch-pits, which correspond with the outcrops of single misfit-induced dislocations that encircle the flat lens-shaped lamellae. A small patch of deuteric coarsening is visible at the extreme left of the image. Micrograph by Amos Aikman.

feldspar (commonly microcline) subgrains (Worden et al. 1990, Lee et al. 1995). In the majority of alkali feldspar crystals in plutonic rocks, both strain-controlled and deuterically coarsened perthites are present, as shown in Figures 1 and 6. In alkali feldspars from granitic bulk-compositions, misfit dislocations afford points of entry for fluids into the crystals, although dislocations are not essential for deuteric coarsening (Worden et al. 1990). In the Shap granite, there is evidence that the formation of patch perthite took place in two stages and was in part non-isochemical. Cross-cutting veins of film perthite formed at $\sim 410^{\circ} \mathrm{C}$ and contain An-bearing albite $\left(\mathrm{An}_{9}\right)$, whereas replacive albitization $\left(\mathrm{Ab}_{>99}\right)$ took place at $<370^{\circ} \mathrm{C}$, after the formation of edge dislocations on film lamellae (Lee \& Parsons 1997a).

Deuterically coarsened areas appear turbid in an optical microscope. The turbidity in alkali feldspar in an ordinary, "fresh" sample of granite or syenite is mainly caused by micropores (usually $<1 \mu \mathrm{m}$ ) that develop at junctions between the subgrains, to subgrain boundaries themselves, and to a much lesser extent to inclusions of clay and other minerals (Worden et al. 1990, Walker et al. 1995). The development of microporosity as a process accompanying many dissolution-reprecipitation reactions in minerals has been discussed by Putnis (2002). Almost all plutonic alkali feldspars show some development of turbidity and concomitant development of patch perthite. Changes range from total recrystallization without however changing grain outlines (Worden et al. 1990), to subtle signs of dissolution at the TEM scale in parts of grains that optically appear "fresh" (Fitz Gerald et al. 2006, see below, present Fig. 12). Rock types most likely to experience minimal deuteric reactions are "dry" igneous and metamorphic rocks, including some syenites (the best known being the larvikite from Oslo used as an ornamental stone, with 
its iridescent cryptoperthitic feldspars), some rapakivi granites (polished rapakivi granite with dark brown feldspars are common in shopping malls), granulitefacies gneisses and related charnockites (in which the glass-clear feldspars can be bottle green in color). These are not common rock-types, and deuteric replacement reactions in alkali feldspars have to be seen as a major feature of the upper crust.

Fluid-feldspar unzipping reactions, and also deformation, are the main ways in which orthoclase overcomes the energy barrier implicit in the tweed texture. In the Shap suite, K-feldspar in pristine film-perthite regions is tweed orthoclase, whereas in deuterically coarsened areas, it is usually microcline (Lee et al. 1995). In microcline, the tartan twins have the same orientation as the tweed, but are enormously coarser, fully ordered, and are triclinic to X-rays and in thin section. Fluid-mediated unzipping of tweed has also been found following retrogression in granulite-facies rocks (Waldron et al. 1993).

\section{Gem-Quality AlKali FeldSPars}

By the time they reach the Earth's surface and can be sampled by passing geologists, alkali feldspars in plutonic rocks have usually acquired a rich inventory of defect microtextures that record both volume-diffusioncontrolled and dissolution-reprecipitation-controlled processes. At the time of their growth, crystals are largely homogeneous, microtexture-free sanidine (except perhaps for grown-in point defects, chemical growth-zones, and possibly inclusions of other minerals, glass and fluids). To measure fundamental properties of the simplest possible alkali feldspar, we require gemquality sanidine that either cooled too rapidly for exsolution to occur or is very Or-rich, and that has not been affected by reactions with aqueous fluids. Acquiring such material is not easy. Many samples of optically homogeneous sanidine, although commonly described in the petrological literature as "unexsolved", are in fact cryptoperthitic, with complex exsolution and twinning,

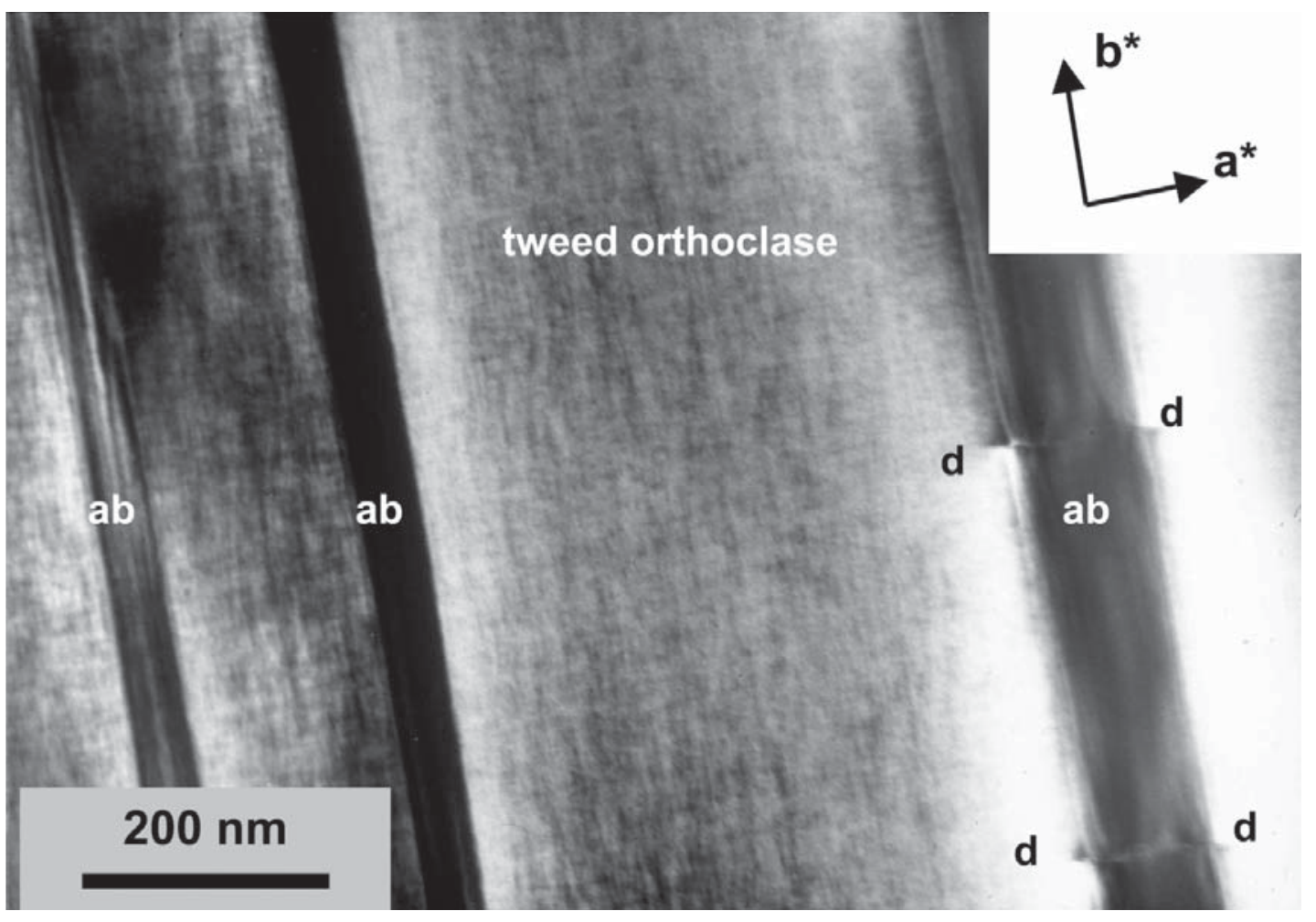

FIG. 5. Bright-field TEM image of a region of a Shap alkali feldspar similar to that in Figure 4, viewed from approximately normal to (001). The orthoclase matrix has a well-developed tweed microtexture. A broad albite lamella to the right is semicoherent, with two dislocation loops (d-d) that are associated with tiny cracks ("pull-aparts", Fitz Gerald et al. 2006). Two thinner lamellae to the left are fully coherent. In this case, coherency strains are accommodated by the tapered ends of the lamellae, well outside the field of view. Albite twins are not visible in the albite lamellae, which are probably twinned on the Pericline law, the composition plane for which is very close to (001) in the Shap feldspars. 


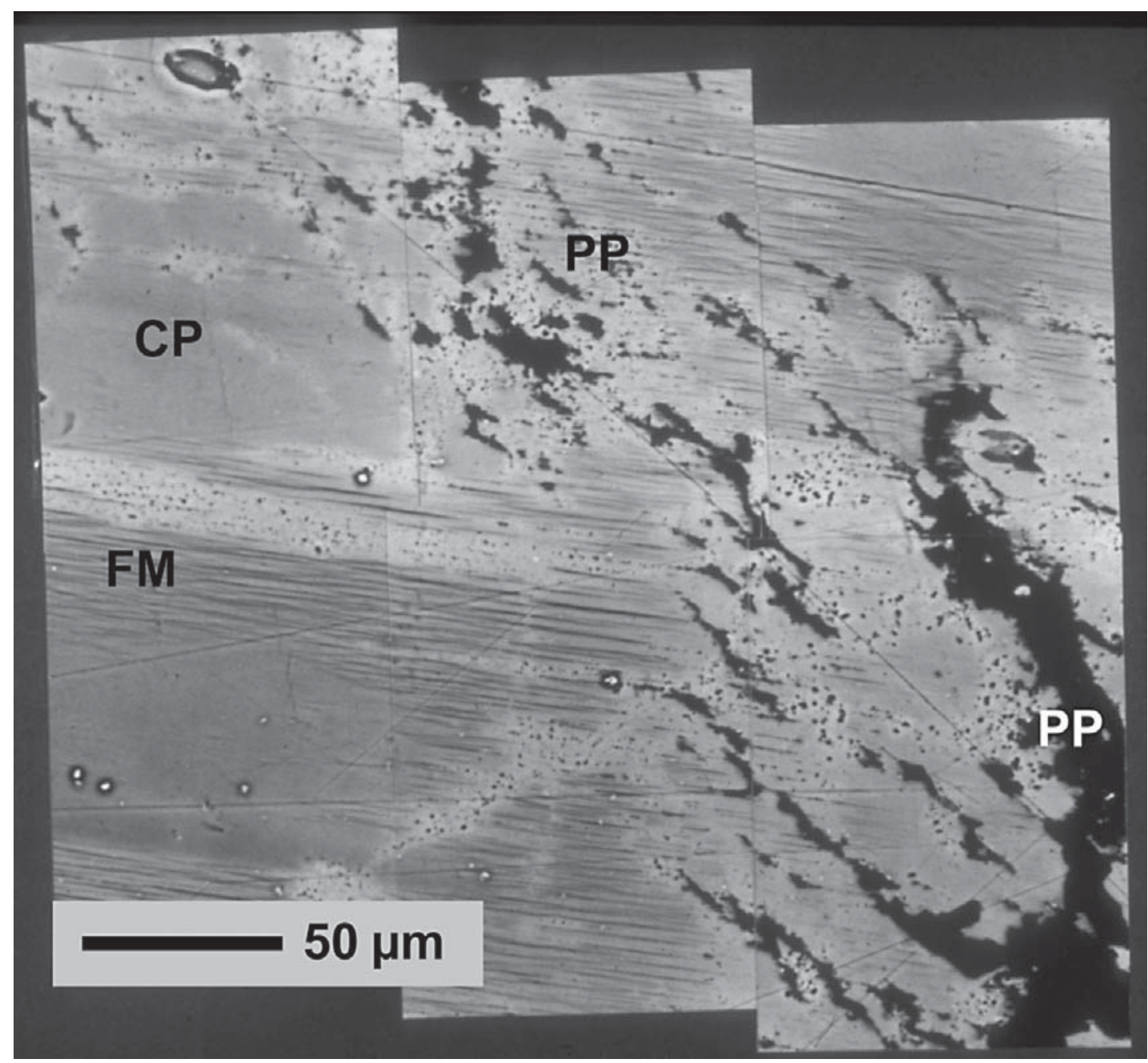

FIG. 6. Montage of back-scattered-electron images (BSE, SEM) of a polished section of a Shap alkali feldspar phenocryst (cf. Fig. 1). Albite appears black, orthoclase medium gray. Very pure microcline associated with micropores (black dots) is light gray. A few oblique straight lines are scratches. In parts of the image, nearly straight, lenticular semicoherent film microperthite (FM) lamellae are visible, but elsewhere the K-feldspar appears non-perthitic (medium gray) at this relatively low magnification, although it is likely to be composed of fully coherent cryptoperthite $(\mathrm{CP})$. These strain-controlled intergrowths are devoid of micropores, and the K-feldspar is tweed orthoclase. Cutting across them, at the right and top center, are ragged regions of deuteric coarsening to patch perthite (PP), clearly associated with micropores. TEM images show that these commonly mark triple junctions between the subgrains of which these regions are composed. Note that some areas of deuteric coarsening are mixtures of albite and microcline, other areas are predominantly of one or other feldspar. This type of microtextural diversity is typical of alkali feldspar from granites and felsic gneisses.

as demonstrated nearly fifty years ago by single-crystal X-ray diffraction (XRD) (Smith \& MacKenzie 1958).

A gem-quality alkali feldspar of great importance to $\mathrm{K} / \mathrm{Ar}$ and ${ }^{40} \mathrm{Ar} /{ }^{39} \mathrm{Ar}$ dating and thermochronology is the orthoclase from a pegmatite at Benson Mines in the Adirondacks, used by Foland (1974) to obtain the activation energy and diffusion coefficient for Ar diffusion in K-feldspars (Fig. 7a). The values he determined are the standard used to this day. Foland \& $\mathrm{Xu}(1990)$ studied the effect of neutron irradiation on Benson orthoclase. Fortunately, Foland characterized his feldspar with great care. It is clear and colorless with a well-developed cleavage, and no optically visible alteration, zoning or twinning. No plagioclase phase could be detected optically or using XRD. To check that no sub-optical albite is present, Foland heated an 
aliquot for three days at $950^{\circ} \mathrm{C}$, and found no change in the diffraction pattern. Chemical analysis indicated a bulk composition of $\mathrm{Or}_{94} \mathrm{Ab}_{6}$, with only $150 \mathrm{ppm}$ of $\mathrm{Ca}$. Cell refinement gave $b$ and $c$ parameters indicating orthoclase. The cell parameters did not change after heating for four weeks at $750^{\circ} \mathrm{C}$ or 10 days at $800^{\circ} \mathrm{C}$ (contrast Eifel sanidine described below). TEM work by R.A.Yund (reported by Foland 1994) revealed no second phases, dislocations or cracks, and a tweed microtexture with a $5 \mathrm{~nm}$ modulation.

Although they are unusually iron-rich, beautiful yellow crystals of glass clear ferriferous "orthoclase"
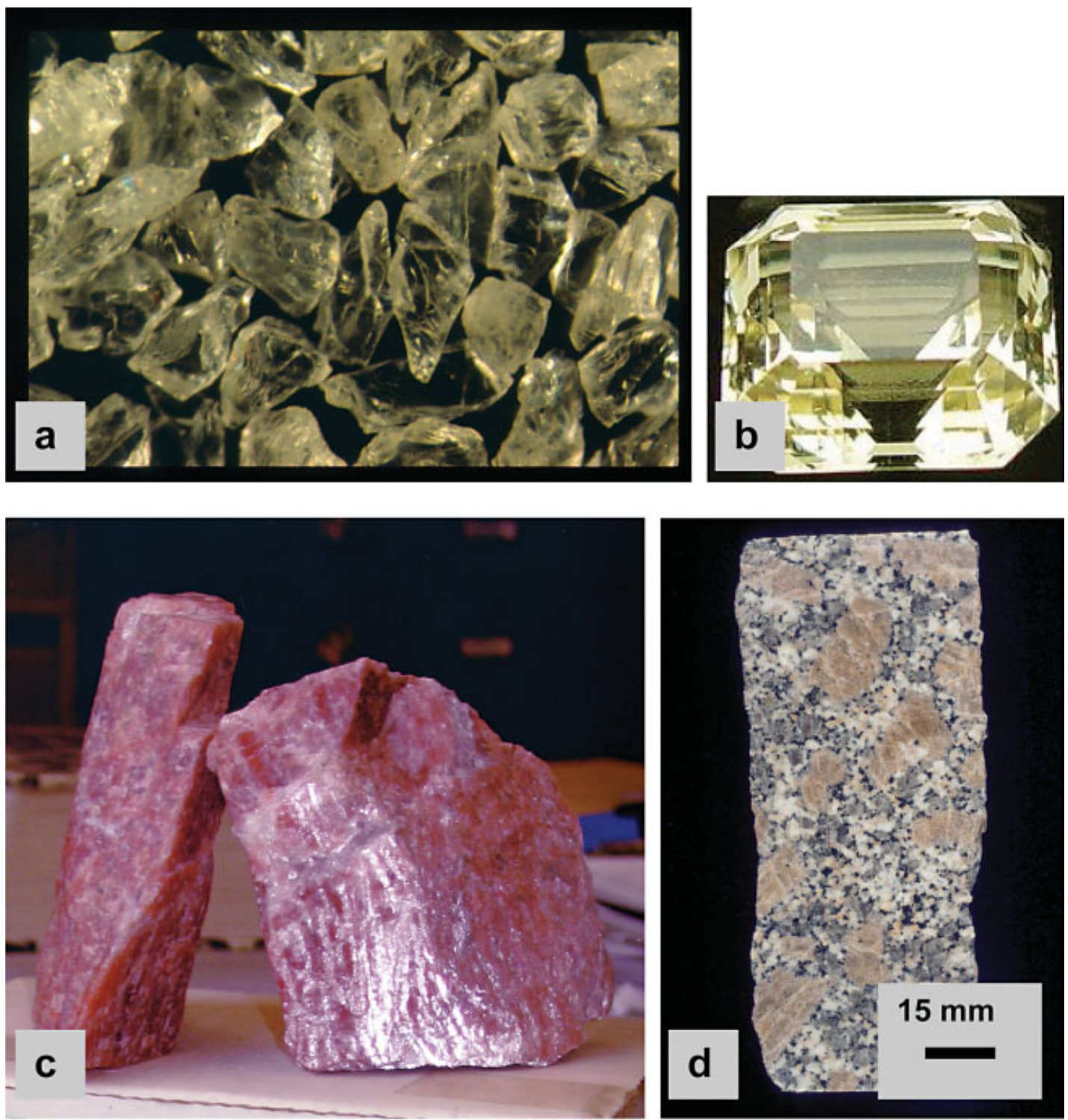

FIG. 7. Different animals, but all K-feldspar. (a) Sized $(480 \mu \mathrm{m})$ fragments of Benson Mines orthoclase used by Foland (1974) to determine the diffusion parameters of argon in K-feldspar (image provided by Ken Foland). (b) Cut gemstone of ferriferous orthoclase from Madagascar. It is $16.9 \times 15 \mathrm{~mm}$. This image was found at www.gggems.com/orthoclase.htm. (c) Type perthite from Perth, Ontario, readily available from Ward's, and much used in experimental work on dissolution. The fragment on the right is $60 \mathrm{~mm}$ high. It is strictly a low albite - microcline macromesoperthite. Note the veins of grey quartz. (d) Polished slab of biotite granite from Shap, Cumbria, showing the pink alkali feldspar phenocrysts. These crystals are much more representative of typical crustal alkali feldspars than either (a), (b) or (c). 
from Itrongay, Madagascar (Fig. 7b), have been much used for experiments in recent years in several important fields: in dissolution experiments relevant to weathering and soil formation (Fenter et al. 2000, Teng et al. 2001), in the study of properties relevant to transport along grain boundaries (Heinemann et al. 2001), in the field of argon diffusion (Villa 1996, Arnaud \& Kelley 1997, Nyfeler et al. 1998, Wartho et al. 1999), in hard-mode infrared spectroscopy (Harris et al. 1989), in a study of thermodynamic mixing properties of an ion-exchange series (Hovis 1988), and in studies of Al distribution using sophisticated electron channeling and diffraction techniques (McLaren \& Fitz Gerald 1987).

The Itrongay "orthoclase" crystals were first reported by Lacroix (1912), who stated that they come from a miarolitic pegmatite. A set of 20 samples were properly characterized by Coombs (1954), who discovered a considerable range in compositions, with iron orthoclase $\left(\mathrm{KFe}^{3+} \mathrm{Si}_{3} \mathrm{O}_{8}\right)$ contents of up to $12.3 \mathrm{wt} \%$, and albite contents up to $9 \%$ (the bulk composition of a sample reported by Coombs as being cryptoperthitic). Optical properties were extremely variable, some samples being high sanidine [OAP parallel to (010)], with $2 V$ up to $50^{\circ}$, others with the OAP normal to (010) and $2 \mathrm{~V}$ of up to $35^{\circ}$. Coombs heated six samples for $160 \mathrm{~h}$ at $1075^{\circ} \mathrm{C}$, after which all had the OAP parallel to $(010)$ and $2 \mathrm{~V}$ between 50 and $56^{\circ}$. There was no relationship between the optical properties of the heated samples and amount of $\mathrm{Fe}_{2} \mathrm{O}_{3}$, suggesting that the optics provide a good guide to degree of $\mathrm{Si}$, Al order, even in these Fe-rich feldspars. Using the curves of $\mathrm{Su}$ et al. (1986), most of the samples of Coombs are high or low sanidine, rather than "orthoclase", as is usually stated.

Unfortunately, many modern investigators have not characterized their samples of "Madagascar orthoclase" in sufficient detail to be sure where their material lay in this variable suite of samples. Teng et al. (2001) reported that back-scattered electron imaging (BSE), cathodoluminescence (CL), and optical microscopy showed no albite exsolution lamellae or other microstructures. Heinemann et al. (2001) stated that their crystals are free of twins, exsolution lamellae and inclusions. Hovis (1988) reported TEM observations by M.A. Carpenter that revealed no tweed texture in his sample of Madagascar orthoclase. Arnaud \& Kelley (1997), in contrast, provided cell angles from XRD showing that their sample is triclinic (although confusingly they describe it as a "medium temperature orthoclase"). Their $b$ and $c$ parameters correspond with considerable $Z$-order, $\mathrm{t}_{1} 0+\mathrm{t}_{1} \mathrm{~m}=0.83$.

We have used TEM to study a fragment of the sample used by Arnaud \& Kelley (1997) and Wartho et al. (1999) for their work on Ar diffusion. The bulk of the fragment thinned by us is composed of potassium feldspar with the "tweed" microtexture characteristic of orthoclase (Fig. 8). The modulations are best developed parallel to $b^{*}$ of the average crystal and are in general $<5 \mathrm{~nm}$ wide, i.e., about six unit-cells thick in the $a$ direction. Less sharply defined modulations occur near the $a-c$ plane. The average symmetry is monoclinic, and this crystal would appear monoclinic to X-rays, as in the Madagascan sample for which a structure was determined by Kimata et al. (1996). Spots on our electrondiffraction patterns show diffuse streaks parallel to $a^{*}$, consistent with short-range departures from monoclinic symmetry. Tweed texture is the defining property of orthoclase, and thus this particular sample of Itrongay feldspar is properly described as orthoclase.

Two further types of heterogeneity occur in our sample. Very thin, flat, lenticular lamellae of albite are encountered sporadically. Their maximum thickness is about $10 \mathrm{~nm}$, but they may be as much as $500 \mathrm{~nm}$ long. Where they are oblique to the tweed texture, they may be long and straight (left lamella in Fig. 8a) or somewhat sinuous. En échelon swarms of shorter lamellae in which individual lamellae are parallel to $b^{*}$ also occur (right lamellae in Fig. 8a). These appear to form where the overall elongation of the swarm is close to $b^{*}$. The absence of damage due to the electron beam along lamellar interfaces, and our experience of many other lamellae of cryptoperthitic albite (e.g., Lee et al. 1995) suggest that such small lamellae are fully coherent. The normal orientation of coherent albite lamellae in orthoclase is a non-crystallographic plane between (601) and (801), i.e., parallel to $b^{*}$, which minimizes elastic coherency strain-energy (Willaime \& Brown 1974). The en échelon lamellae in our Itrongay sample thus seem to have formed from a continuous lamella in some other plane; if this plane was close to $(\overline{601}) /(\overline{801})$, the lamella segmented and the segments rotated closer to the optimum orientation, but if the original plane was far from the optimum orientation, rotation could not occur. Their presence further suggests that the original lamellae nucleated on some externally imposed defect, either a fracture, or a planar region of high, externally imposed strain. Because of the Or-rich bulk composition of the crystals, coherent exsolution would have occurred at very low temperature, probably below $200^{\circ} \mathrm{C}$ (Fig. 2), although the effect of the relatively high $\mathrm{Fe}$ content is not known. The abundance of lamellae is not as high as the $\sim 5 \%$ albite implied by the chemical analyses of the bulk sample, so some Na remains in solid solution in the orthoclase phase.

The third type of heterogeneity seen using TEM consists of pervasively distributed oval particles, typically $\sim 25$ by $15 \mathrm{~nm}$ in size (Fig. 8b). The density of distribution is in places $2-3 \mu \mathrm{m}^{-2}$. The inclusions are crystalline, because their diffraction contrast varies (Fig. 8b). The chemical composition of these inclusions is not known, but it is likely that they are the Fe-rich phase detected by Klein et al. (1996) using Mössbauer and EPR spectroscopies.

It seems therefore that Ar diffusion coefficients have yet to be obtained for an Or-rich feldspar totally devoid of microtexture. It is not obvious whether the coherent interfaces of tweed domains will increase or 

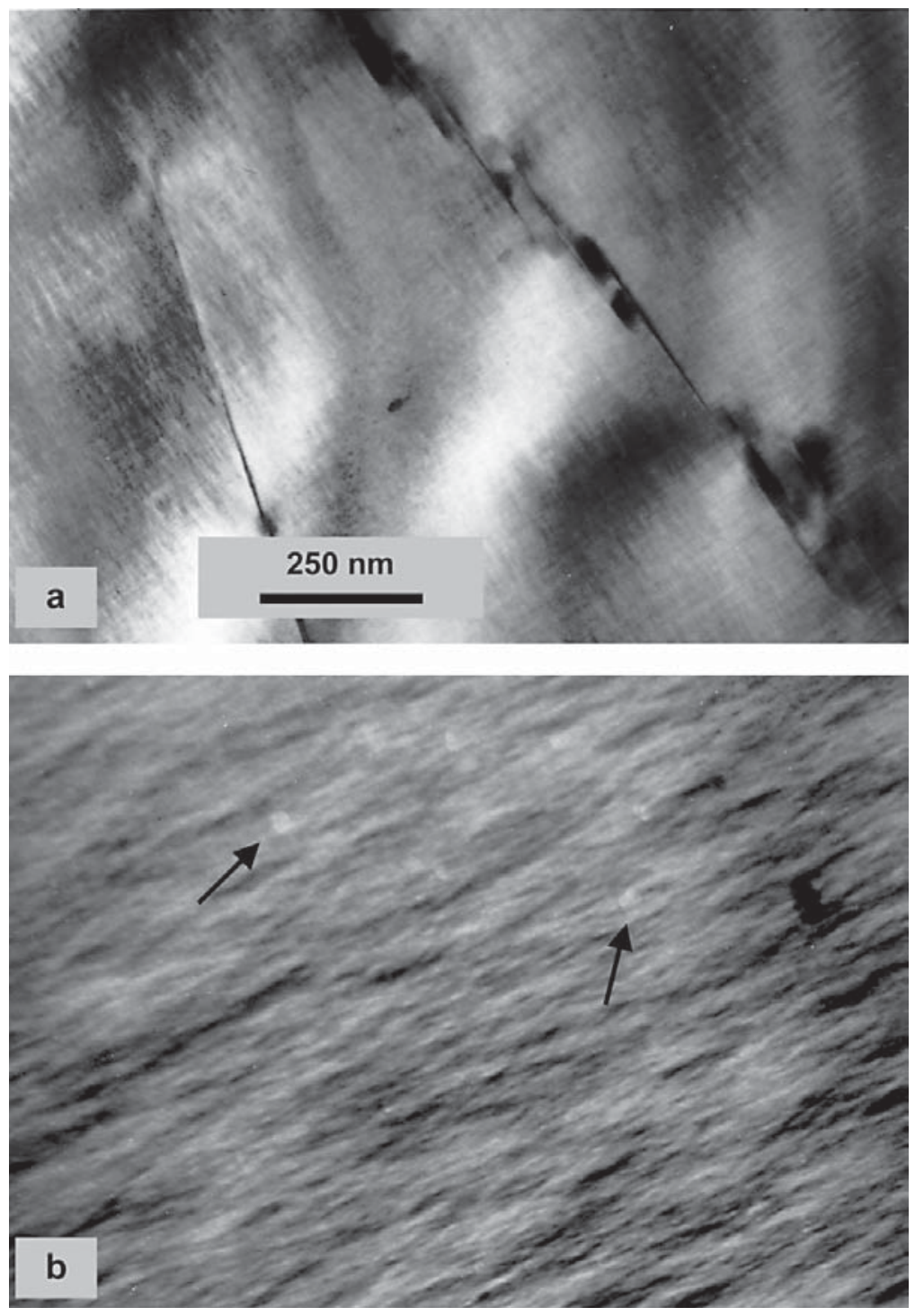

FIG. 8. Bright-field TEM micrographs of a Madagascar orthoclase. Foil viewed close to [001]. (a) Orthoclase with well-developed tweed microtexture containing extremely fine lamellae of albite. An en échelon swarm of short lamellae occurs to the right, and a longer solitary lamella at the left. (b) Enlargement showing small subcircular inclusions of a second phase, probably Fe-bearing, at the top. Some are diffracting strongly (dark), whereas others are diffracting less strongly (light). Two examples are marked with arrows. The inclusions are therefore crystalline, and do not share a common crystallographic orientation.

decrease the diffusion rates of Ar relative to domain-free sanidine, as impurities can be trapped at boundaries or move more rapidly along them. Foland (1974) discussed the extremely large variations in diffusion coefficients (six or seven orders of magnitude) obtained for alkali feldspars in general, and concluded that perthitic intergrowths would exhibit complex behavior and would in general have effective scales of diffusion considerably smaller than the grain size, leading to low $\mathrm{K}-\mathrm{Ar}$ and ${ }^{40} \mathrm{Ar} /{ }^{39} \mathrm{Ar}$ ages. Foland was certainly correct in the case 
of strain-free, deuterically coarsened perthites and probably correct for many semicoherent perthites, but fully coherent perthites, even where of very fine scale, retain $\mathrm{Ar}$ and behave as essentially homogeneous phases for Ar diffusion (Parsons et al. 1988). Factors controlling Ar diffusion in microtexturally complex feldspars were reviewed by Parsons et al. (1999). The field of ${ }^{40} \mathrm{Ar} /{ }^{39} \mathrm{Ar}$ thermochronology provides an excellent example of the absolute necessity for mineral microtextural and geochemical information to be used in a complementary way if we are to reach robust geological conclusions.

Another example of contrasting behavior of gemquality and "garden-variety" alkali feldspars comes from the field of luminescence dating. This is potentially a powerful tool for determination of the duration of time that geologically young sediments have been buried and shielded from sunlight. Although feldspar (mainly alkali feldspar) and quartz can all be used for dating, almost all practitioners use quartz, even though it is inferior to alkali feldspar for the dating of sediments at the younger end of the age spectrum accessible by the technique. Alkali feldspar is unpopular owing to the belief that most if not all grains are affected by the phenomenon of "anomalous fading", whereby they retain only a portion of the signal that they acquire and should store during natural irradiation within their host sediment (Wintle 1973). A number of investigators have shown that volcanic sanidine, including the Eifel sanidine described in the next section, loses its signal very rapidly after laboratory irradiation (Spooner 1994, Zink et al. 1995, Visocekas \& Zink 1999), whereas "garden-variety" alkali feldspars from plutonic igneous rocks are much less prone to fading (Spooner 1994, Hütt et al. 1993). The reasons why gem-quality sanidine fades so rapidly are currently unknown, but most authors suggest that it is related to the state of $\mathrm{Si}-\mathrm{Al}$ order, although few if any luminescence specialists have actually determined the state of order of their experimental samples, and many do not even quote the bulk chemical composition of their feldspars. As most investigators concerned with investigating the physical mechanisms of fading have focused their attention on gem-quality volcanic sanidine, a false impression has been created that fading is a generic phenomenon of alkali feldspars. This important phenomenon can be understood and its deleterious effects mitigated only once work has been undertaken to determine the luminescence properties of "gardenvariety" alkali feldspars typical of those that actually occur within the types of sediments being dated (see the final section for examples of such feldspars).

\section{Eifel sanidine}

The most perfect crystals of sanidine known were erupted from the Laacher See volcano in the Eifel district in the Rhine Valley 12880 years ago, and are often simply called "Eifel sanidine", although there are many variants, some with beautiful chemical zoning recently described by Ginibre et al. (2004), reflecting processes in the underlying Laacher See magma chamber. Single crystals up to $10 \mathrm{~kg}$ in weight have been found (Bank 1967). The most intensely studied material comes from a tuff at a locality called Volkesfeld. It is devoid of exsolution textures, and has been shown by TEM (Willaime \& Gandais 1977, Willaime et al. 1979), $\gamma$-ray diffraction (Gering 1985) and X-ray topography (Widder et al. 1994) to be exceptionally perfect, with dislocation densities of $<10^{6} \mathrm{~cm}^{-2}$, in places as low as $10^{3} \mathrm{~cm}^{-2}$. Crystal regions of several $\mathrm{cm}^{3}$ may be nearly perfect (Widder 1991). Hovis (1988) reported TEM observations of M.A. Carpenter that revealed no tweed texture. Some samples are colorless and perfectly transparent, others are the color of smoky quartz, but become colorless on exposure to sunlight or after annealing (Zeipert \& Wondratschek 1981, Widder et al. 1994). This paragon of the feldspar race has been used for studies of various types, including deformation mechanisms (Willaime \& Gandais 1977, Willaime et al. 1979, Kovacs \& Gandais 1980), the role of defects in weathering (Murphy 1989, Lee et al. 1998) and the related factor of surface roughness (Hodson et al. 1997, Hodson 1998), use as a precise analytical standard for the identification of anomalous compositions (Teertstra et al. 1998), and IR studies of "water" speciation in a nominally anhydrous silicate (Lehmann 1984, Hofmeister \& Rossman 1985, Beran 1986).

The Volkesfeld sanidine, geologically very young and brought rapidly to the surface from its point of growth 3.5 to $7 \mathrm{~km}$ below (Ginibre et al. 2004) has, however, some strange properties which should make us think seriously about how closely crystals that have taken long periods of time (in some cases hundreds of millions of years) to reach the surface after growth at depth in the Earth, resemble in physical properties the same material in situ. The Eifel sanidine sensu lato consists of high sanidine with its optic axial plane parallel to (010) and a small $2 \mathrm{~V}$, between 0 and $20^{\circ}$ (Bertelmann et al. 1985) and there is some variation in composition, with the majority of analyses giving $\sim \mathrm{Ab}_{15} \mathrm{Or}_{85}$, with very low An (e.g., $0.1 \mathrm{~mol} . \%$, Kroll \& Knitter 1991). In terms of $\mathrm{Si}-\mathrm{Al}$ order, they therefore have $2 \mathrm{t}_{1}$ of $0.62-0.63$, corresponding with the order parameter $Z=0.24-0.26$, using the curves of Su et al. (1986). Similar estimates of $2 \mathrm{t}_{1}$ can be obtained from cell parameters.

Low albite was first synthesized by Martin (1969), but the transformation from low sanidine to microcline has not been achieved experimentally, and this has led to the view that ordering in $\mathrm{KAlSi}_{3} \mathrm{O}_{8}$ is intrinsically more sluggish than in $\mathrm{NaAlSi}_{3} \mathrm{O}_{8}$. Brown \& Parsons (1989), however, reviewed existing experimental data and argued that rates of ordering in sanidine and microcline were similar to those in albite; it is ordering in orthoclase, with its alternating "left" and "right" domains forming the tweed microtexture, that is ordersof-magnitude slower. Nevertheless, both disordering 
and ordering rates in most samples of $\mathrm{K}$-feldspar are relatively slow, including the gem-quality orthoclase from Madagascar discussed above (Priess 1981) and sanidine from several other localities (Bertelmann et al. 1985).

However, the very perfect sanidine from Volkesfeld orders and disorders reversibly with extraordinary rapidity, and shows larger changes in order at lower $T$ than other samples of sanidine. Following preliminary work by Zeipert \& Wondratschek (1981), Bertelmann et al. (1985) annealed slabs of sanidine crystals "dry" between 750 and $1050^{\circ} \mathrm{C}$ and traced the change in $2 V_{\mathrm{x}}$ with time. An "equilibrium optic angle" was reached in a few hours at $1050^{\circ} \mathrm{C}$ and $\sim 100-200 \mathrm{~h}$ at $750^{\circ} \mathrm{C}$. This is slightly faster than the equilibration rate for albite at this $T$ with $\mathrm{H}_{2} \mathrm{O}$ at $0.1 \mathrm{GPa}$, found by MacKenzie (1957). Samples heated at $1050^{\circ} \mathrm{C}$ disordered considerably in only 15 minutes and when then heated at 950, 850 and $650^{\circ} \mathrm{C}$, they approached but did not exactly reach the "equilibrium" values at these $T$; these values provided loose brackets of the "equilibrium" values. The rate of approach to equilibrium was found to depend on $T$ and prior heat-treatment. For example, prolonged heat-treatment at $650^{\circ} \mathrm{C}$, which produced no change in $2 V_{\mathrm{x}}$, had the effect of slowing the approach to an equilibrium value when the sample was subsequently annealed at a higher temperature. Rates of disordering were similar to those in other samples of sanidine. The same effect occurred following shorter periods of pre-annealing at higher $T$.

Bertelmann et al. (1987) and Bernotat-Wulf et al. (1988) studied this loss of reactivity. Ordering and disordering were found to be faster in the central areas of thick slabs. Slabs less than $2 \mathrm{~mm}$ thick, and powders, reacted no more rapidly than other samples of sanidine. The loss of reactivity started from the surface and moved inward with time. Bertelmann et al. reported that large irregularly shaped pores associated with dislocations developed mainly in the $(010)$ plane, and that at low $T$, a fluid or a solid phase (ice) condensed in a few of them. These "inclusions" may be caused by the exsolution of $\mathrm{H}_{2} \mathrm{O}$ from the feldspar, most of which is lost to the outside by diffusion along dislocation cores. Beran (1986) found $0.036 \mathrm{wt} \% \mathrm{H}_{2} \mathrm{O}$ in a piece of Volkesfeld sanidine, Lehmann (1984), 0.013 wt \%, and Hofmeister \& Rossman (1985), 0.017 wt \% . Beran used polarized IR spectroscopy to suggest that the $\mathrm{H}_{2} \mathrm{O}$ molecules are structural constituents in the feldspar $M$ site.

In short, some Eifel sanidine seems to go to sleep when subjected to repeated annealing, and to lose the ability to order and disorder rapidly. This change in behavior takes place first close to crystal surfaces. It seems that a mystery ingredient that is not normally present in less perfect sanidine crystals is being lost from the cyrstals. Probably this is a hydrogen species. Goldsmith (1988) showed the importance of hydrogen on ordering and disordering in microcline at 0.7-1.4 $\mathrm{GPa}$, suggesting that the relevant species is $\mathrm{H}_{2}$, but
Graham \& Elphick (1990) reinterpreted Goldsmith's experiments and showed convincingly, in experiments on ordering in albite in which $a \mathrm{H}^{+}$was carefully controlled, that $\mathrm{H}^{+}$(protons) was the active species. The nature of hydrogen species in silicates remains rather controversial [see Kronenberg et al. (1996), and discussion by Doremus (1998) and Kronenberg et al. (1998)]. The rapid loss of ordering ability from the margins of plates of Volkesfeld sanidine and the exceptionally rapid $\mathrm{Si}$,Al ordering seen are consistent with a very mobile species. Probably, protons have been retained in the unusually perfect and geologically very young crystals, and these have been lost from more normal feldspars. This, of course, immediately raises the question: is Volkesfeld sanidine more representative of feldspars as they are at depth in the Earth than all the "ordinary" feldspars we study?

\section{RATES OF ORDERING AND EXSOLUTION IN NATURE}

Attempts have been made to relate $\mathrm{Si}-\mathrm{Al}$ order in sanidine to cooling rate calculated from geological considerations. Scott et al. (1971) studied sanidine crystals from a 300-m-thick ignimbrite from Nevada in which $2 V_{\mathrm{x}}$ lies between 0 and $42^{\circ}$, with the optic axial plane perpendicular to $(010)$ and a composition near $\mathrm{Ab}_{23-27} \mathrm{Or}_{72-75} \mathrm{An}_{1-2}$. They found variations in order and visibility of exsolution textures with height in the ignimbrite, those in the center being the most ordered and most strongly exsolved. From heat-loss models, they calculated approximate cooling times down to $500^{\circ} \mathrm{C}$, and obtained values of $100-200$ years near the base and top and up to $450-650$ years in the center. Equivalent equilibrium temperatures calculated from experiments on ordering of the Eifel sanidine (Bertelmann et al. 1985) vary from $\sim 550^{\circ} \mathrm{C}$ in the center to $\sim 730^{\circ} \mathrm{C}$ at the top and bottom. Thus, sanidine crystals in the ignimbrite must have ordered considerably more slowly than those from the Eifel.

Kroll \& Knitter (1991) investigated the ordering kinetics of two samples of sanidine from Volkesfeld. Like Bertelmann et al. (1987), they showed that preheating greatly slows ordering rates. They proposed a model for calculating cooling paths and considered that the ordering kinetics of their preheated sanidine were more "normal" than those of the unusually reactive crystals studied by Zeipert \& Wondratschek (1981) and Bertelmann et al. (1985). However, it might be argued that in nature, in the Trange in which sanidine is stable, the very perfect Eifel material is the more "normal". Until the reasons for the behavior of the Eifel material are understood, there remain serious objections to the use of $\mathrm{Si}-\mathrm{Al}$ order in sanidine as a cooling-rate meter. If the rate is indeed controlled by an ephemeral $\mathrm{H}$ species, some way of estimating $a \mathrm{H}^{+}$during cooling will be required.

Although $\mathrm{Na}^{+}$and $\mathrm{K}^{+}$diffusion in Ca-free feldspars seems to be independent of the presence of $\mathrm{H}_{2} \mathrm{O}$ [see 
Yund (1984) for a thorough review of this complex subject], most natural alkali feldspars contain some An, and in this case rates of $\mathrm{Na}^{+}$and $\mathrm{K}^{+}$diffusion may be controlled by the framework, because $\mathrm{Ca}^{2+}$ partitions into the $\mathrm{Ab}$-rich phase and is charge-coupled to $\mathrm{Al}^{3+}$. "Water" enhances diffusion rates of framework ions. Thus coarsening rates of cryptoperthitic material may be controlled by the framework and not simply by Na-K interdiffusion (Brown \& Parsons 1984a). Although a study of lamellar periodicities of cryptoperthite in rhyolites (Yund \& Chapple 1980) gave geologically reasonable estimates of cooling rate using the experimental data on coarsening of Yund \& Davidson (1978), a study of cryptoperthite samples (bulk composition $\mathrm{Ab}_{33} \mathrm{Or}_{66} \mathrm{An}_{1}$ ) from the Bishop Tuff (Snow \& Yund 1988) showed that the periodicity of albite lamellae produced by spinodal decomposition is an order of magnitude larger than predicted by cooling models. It is possible that during spinodal decomposition, the feldspars contained $\mathrm{H}^{+}$like those in the tuffs from Eifel, and that the rate of framework-controlled exsolution was enhanced. The Bishop Tuff is $0.7 \mathrm{Ma}$ old, so no vestige of $\mathrm{H}^{+}$is likely to remain.

Another intriguing hint that coarsening rates are dependent on an ephemeral $\mathrm{H}$ species can be found in a study by Brown et al. (1983) of ordered braid crypto- and fine microperthites in the Klokken syenite intrusion. The layered syenites are composed of two interleaved textural types (Fig. 9a), of generally similar composition, around $\mathrm{Ab}_{60} \mathrm{Or}_{40}$, with $<5$ mol. $\%$ An. Sheets of a fine-grained, slightly less evolved "granular syenite" are enclosed by much coarser, slightly more evolved "laminated syenite". These two types cooled as a single body into the $T$ range of exsolution and coarsening. Both show a simple straight-line relationship between the log of the lamellar periodicity and height in the layered series (Fig. 9b), from only $40 \mathrm{~nm}$ in the finest intergrowths at the top of the intrusion (comparable to many volcanic rocks) to $400 \mathrm{~nm}$ in the coarsest intergrowths $600 \mathrm{~m}$ below. Periodicities in the highest samples of granular syenite are similar to values in volcanic alkali feldspars, suggesting that the section shown in Figure 9a is very close to the roof of the magma chamber. The downward coarsening reflects cooling rate, but curiously the periodicities in the two types of syenite each define different, subparallel lines on a height versus log periodicity plot, with longer periodicities in the more evolved syenites. Because exsolution, ordering and twinning are all coupled in these samples of slowly cooled cryptoperthite, Brown et al. (1983) speculated that the laminated syenites crystallized from a more evolved, and therefore more hydrous magma, the feldspars incorporating "water" either as $\mathrm{H}_{3} \mathrm{O}$ or $4 \mathrm{H}$, replacing $\mathrm{Si}$.

The unusual diffusional properties of sanidine from Eifel may not be restricted to rates of $\mathrm{Si}-\mathrm{Al}$ ordering and disordering. Foland (1974) compared the rate of Ar diffusion in Benson Mines orthoclase with that in various samples of sanidine from the literature (his Fig. 4). Three apparently homogeneous crystals of sanidine were shown to have diffusion parameters similar to Benson, but three samples, all from Eifel, have Ar diffusivities 2-3 log units faster than Benson. It would be interesting to redetermine diffusion parameters for Ar in carefully characterized Eifel sanidine, and to see if Ar diffusivities change following heat treatment of various lengths of time.

It seems that the peculiar properties of Eifel sanidine may provide a rare glimpse of what is normal in the Earth's middle to lower crust, in crystals shortly after their original growth. The exceptional perfection, rapid rise to the surface and geological youth of the Eifel crystals make them very different from ordinary feldspars, but this is because the latter pass through so many defect-inducing processes on their slow rise toward the surface that all vestiges of their pristine beginnings are lost, together with structural $\mathrm{H}^{+}$or other $\mathrm{H}$ species that can potentially have marked effects on rates of ordering and exsolution, and on rheological properties (Green \& Jung 2005).

\section{Starting Materials fOR Dissolution EXPERIMENTS: FELDSPARS FROM PEGMATITES}

Having discussed above the behavior of alkali feldspar crystals shortly after their birth at relatively high $T$, we now turn to their behavior at the end of their lives, during weathering, transport and diagenesis. Because of their importance in weathering and soil formation, there have been many experimental studies of the solubility of feldspars and the mechanisms and kinetics of their dissolution and alteration near $25^{\circ} \mathrm{C}$ in water and various solutions of a range of $\mathrm{pH}$, including solutions containing organic complexes. A thorough review of experimental work and theoretical considerations was provided by Blum (1994). Only a few key papers are referenced here. One can break down the problem into three interwoven subareas: (1) processes at the atomic level on crystallographically perfect or near-perfect surfaces, (2) the surface area of reacting particles and its evolution during dissolution, and (3) the role of reactive sites on grain surfaces, both during laboratory experiments and during natural weathering. It is with the third of these that we are mainly concerned here. As we shall see, topic (3) is intimately connected in nature, but not the laboratory, with topic (2).

The role of crystal microtextures in feldspar weathering has been long appreciated (e.g., Wilson 1975). Berner \& Holdren $(1977,1979)$ showed examples of selective etching of parts of a grain surface, stating that it was probably related to dislocations, and Lasaga \& Blum (1986) analyzed the role of dislocations in the formation of etch pits. Eggleton \& Buseck (1980b) used TEM to explore the development of holes in feldspars. Murphy (1989) compared rates of dissolution of deformed and undeformed Eifel sanidine. Velbel 

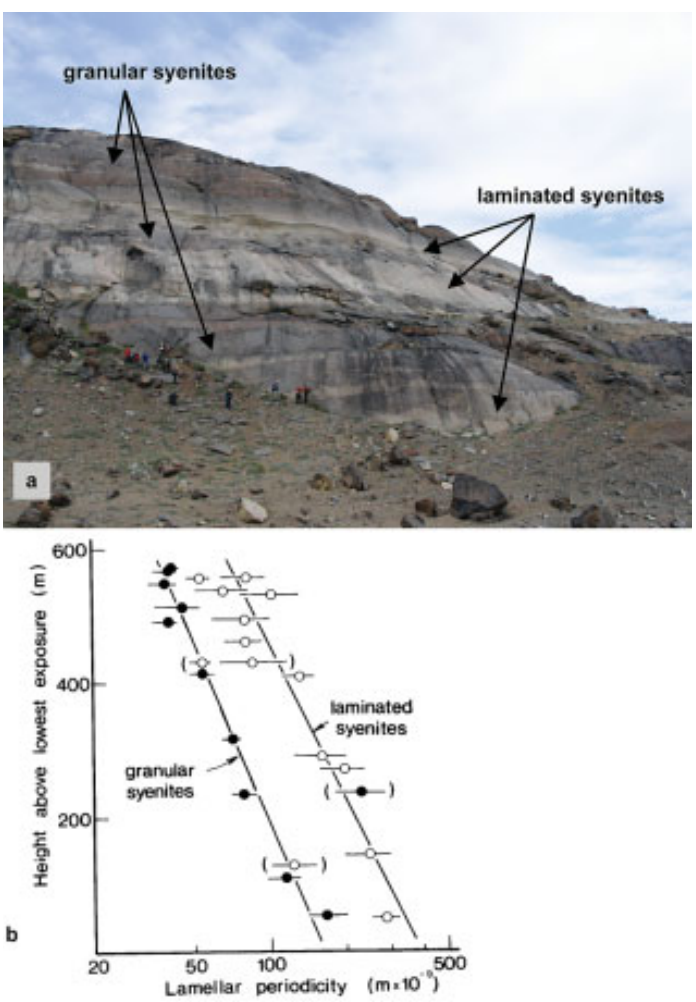

FIG. 9. (a) The upper part of the layered syenite series in the Klokken intrusion, South Greenland. Figures for scale at the base of the cliff on the left. Examples of the two texturally different types of syenite are marked. Grains of alkali feldspar in the brown granular syenite consist of pristine cryptoperthite, whereas those in the laminated syenite are deuterically altered and turbid, giving the pale coloring, although they contain relict volumes of cryptoperthite. (b) Lamellar periodicity $(\mathrm{nm})$ of cryptoperthite in both syenite types (on a log scale) plotted against height $(\mathrm{m})$ in the layered series (after Brown et al. 1983). Lines are linear regressions; the points in brackets are omitted for reasons discussed by Brown et al. Data for the upper $100 \mathrm{~m}$ correspond with the section shown in (a).

(1989), in a particularly important paper, stressed the importance of defects on dissolution rates in solutions close to equilibrium with the solid, compared with solutions far from equilibrium.

Because most experimentalists in this field were seeking to obtain solubility and rate data that could be applied globally, one might have expected that they would take steps to ensure that their experimental materials were either crystals of gem-quality perfection (and therefore the end-members of a range of feldspar microtextural types) or were representative of the most common "garden-variety" types of feldspar in the crust. Alkali feldspars in the first category that have been used for studies relevant to weathering include Madagascar orthoclase (Fenter et al. 2000, Teng et al. 2001), and Eifel sanidine (Petrovic 1976, Althaus \& Tirtadinata 1989, Murphy 1989, Hodson et al. 1997, Lee et al. 1998), both described above. Curiously, though, when looking for "garden-variety" alkali feldspars, most experimentalists have turned to pegmatites for their starting materials, particularly those that can be obtained from Wards Scientific. Names like Perth (Ontario) perthite (Fig. 10a-c), Hybla (Ontario) microcline and Keystone (South Dakota) microcline (Figs. 10d-f) resound for those familiar with the literature. However, fascinating though they undoubtedly are, pegmatites are volumetrically minor constituents of the Earth's crust. It is K-feldspars from subsolvus calc-alkaline granites (which are, in turn, chemically and texturally very similar to K-feldspars in amphibolite-facies gneisses) that are major crustal constituents. In fact, as far as we can tell (since some authors in the experimental dissolution field give no information about the source or even composition of their feldspars), work by our group on natural and experimental weathering of alkali feldspar phenocrysts from the granite at Shap is the only detailed study of the dissolution and natural weathering of a truly "ordinary" plutonic alkali feldspar (Hodson et al. 1997, Hodson 1998, Lee \& Parsons 1995, Lee et al. 1998).

Černý (1994) has reviewed the evolution of feldspars in granitic pegmatites and illustrated their microtextural diversity, and Fitz Gerald \& McLaren (1982) studied microcline samples of pegmatitic origin using TEM. We have studied two pegmatitic feldspars that have been used in dissolution work, so-called Perth perthite and Keystone microcline (abbreviated to Perth and Keystone below), obtained from Wards Natural Science Establishment Inc., using TEM and SEM, to see how closely they resemble the feldspars from Shap. Their highly complex microtextures are summarized below and will be described in more detail at a later date. Holdren \& Speyer (1987) provided bulk analyses of powders of three size-fractions of both samples (each set averaged here in Table 1), and Hodson et al. (1997) provided electron-microprobe data for the macroperthitic albite and microcline, the latter itself containing cryptoperthitic albite, of which the samples are composed (Table 1). The slightly higher An content reported by Holdren \& Speyer (1987) is probably due to plagioclase inclusions in powders of the bulk sample. Holdren \& Speyer $(1985,1987)$ and Hodson et al. (1997) were concerned with the relationship between surface area [as measured by the Brunauer, Emmett $\&$ Teller (BET) gas-adsorption method, see later] and reaction rate.

Perth is medium-red in color and has a more Abrich bulk composition (Table 1) than feldspars from typical subsolvus granites, whereas Keystone is white and similar in composition to many alkali feldspars from granites. In our Keystone sample, the microcline is extensively altered to white mica. Both feldspars should properly be described as microcline macro- 

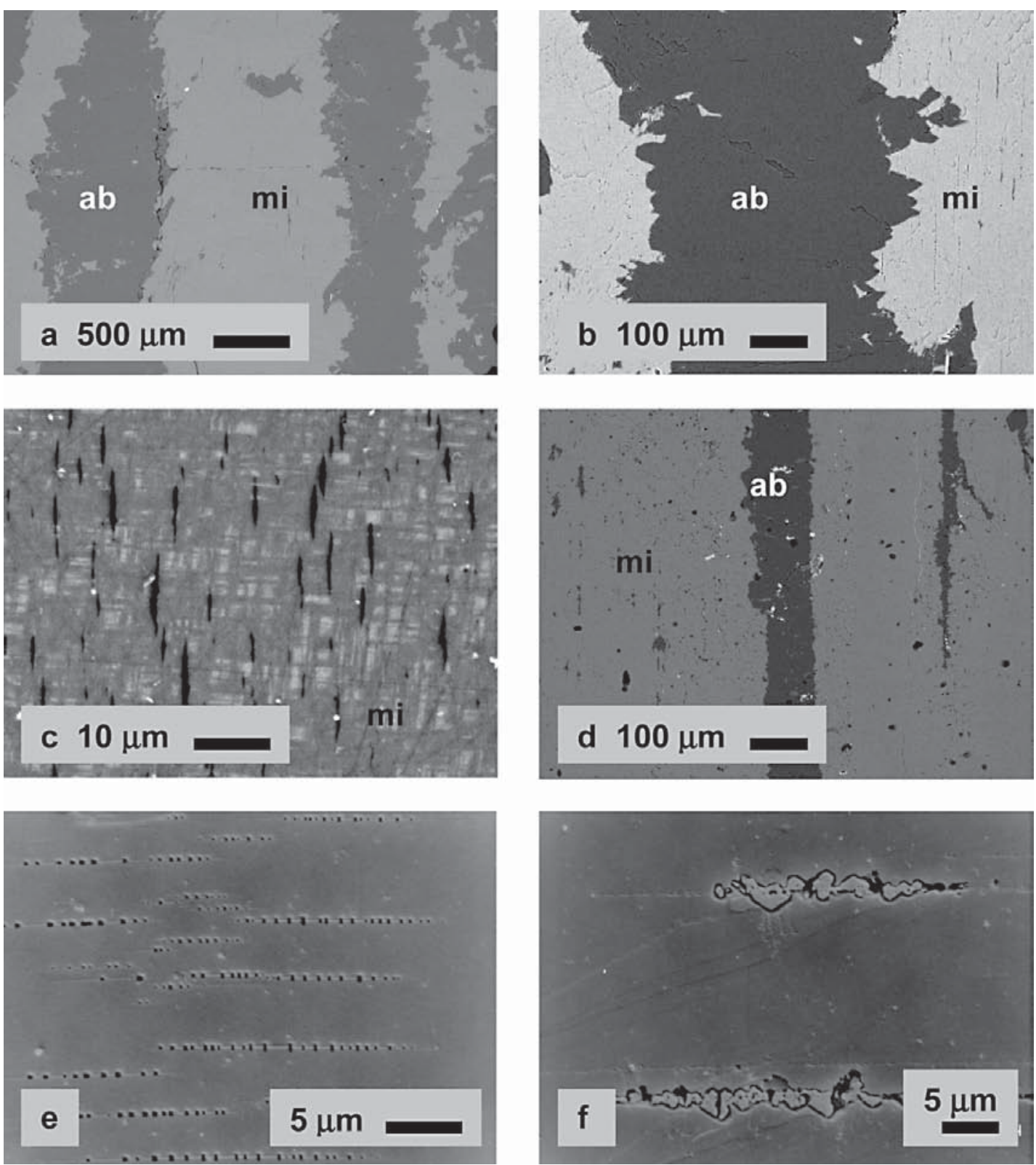

FIG. 10. SEM images of textures in alkali feldspars from pegmatites that have been used for laboratory studies of dissolution. (a), (b) and (d) are BSE images, (c) is a cathodoluminescence (CL) image, and (e) and (f) are SE images. (a) The type perthite from Perth, Ontario, showing very coarse macroperthitic character, with albite dark grey, microcline light grey. (b) Detail of an albite vein showing extremely complex surface with euhedral outgrowths of albite. At this magnification, strain-controlled cryptoperthitic albite lamellae are just visible in the microcline. (c) CL image showing tartan twinning in microcline, and lens-shaped pores (black) where semicoherent lamellae of albite have dissolved naturally. (d) Microcline macroperthite from Keystone, South Dakota, which has a more Or-rich bulk composition than the Perth sample. Note bands with many micropores (black dots) bordering the albite lamellae. (e) HF-etched surface of Keystone microcline showing semicoherent cryptoperthitic albite lamellae and dislocation etch-pits. (f) Image of a grain of cryptoperthite (HF-etched) showing replacive albite, with the $\{110\}$ habit growing from cryptoperthitic lamellae of albite. This type of replacement is also very common in the Shap granite. 
perthite because they contain broad irregular veins of nearly pure Albite-twinned albite cutting microcline (Fig. 10). In Perth, these are roughly parallel to (100), up to $700 \mu \mathrm{m}$ wide and typically $1 \mathrm{~mm}$ apart (Fig. 10a). In Keystone, the veins are generally thinner, $\sim 50-400$ $\mu \mathrm{m}$, and occur in two sets, one roughly parallel to (100), the other at $60^{\circ}$, close to $\{110\}$. The interfaces of the veins with host microcline are extremely irregular, with euhedral outgrowths of albite particularly well developed in Perth (Fig. 10b). The outgrowths show CL zoning with the outer $50 \mu \mathrm{m}$ being non-luminescent. In Keystone, vein surfaces are more ragged and in detail more curved (Fig. 10d), and microcline in the vicinity of the albite veins is very microporous. The microcline matrix of Keystone also contains blocky inclusions of Albite-twinned albite a few tens of $\mu \mathrm{m}$ in size, which on (001) sections are roughly parallel to (100). These may account for the $1 \%$ An found in the bulk sample by Holdren \& Speyer (1987) and would correspond with a plagioclase $\mathrm{Ab}_{95} \mathrm{An}_{5}$. The extreme purity of the albite in the veins in both feldspars is strongly suggestive of crystallization at a very low $T$, analogous to that of diagenetic albitization, and the facetted surfaces suggest replacement (Worden et al. 1990). Whether the albite has been introduced into the crystals from an external source or represents isochemical recrystallization is not known.

The microcline in both feldspars is itself cryptoperthitic or a fine-scale microperthite. Many text books report that cryptoperthite is characteristic of rapidly cooled, commonly volcanic rocks, but this is simply wrong. Using electron microscopy, we and our coworkers find cryptoperthite in almost all samples of alkali feldspar, commonly on a variety of scales, including extremely slowly cooled granulitefacies metamorphic rocks (Cayzer 2002, present Fig. 11b; see also Evangelakakis et al. 1993). The bulk compositions of the cryptoperthite areas in the Perth microcline $\left(\mathrm{Ab}_{7.2} \mathrm{Or}_{92.8} \mathrm{An}_{0}\right)$ and Keystone are similar $\left(\mathrm{Ab}_{5.7} \mathrm{Or}_{94.3} \mathrm{An}_{0}\right)$ (Table 1), and both have exsolved coherent lenticular albite lamellae that developed encircling edge-dislocations as they coarsened (Fig. 10e). These are similar to film lamellae in the Shap feldspars (Figs. 1, 4 and 5), but the Shap feldspars have much more Ab-rich bulk compositions than the cryptoperthitic areas of the two feldspars from pegmatites. The Orrich bulk compositions of the cryptoperthitic Perth and Keystone microcline regions imply an extremely low $T$ for coherent exsolution. From the strain-free solvus for ordered feldspars obtained by Bachinski \& Müller (1971), the minimum $T$ (at atmospheric $P$ ) at which the microcline could have grown as a homogeneous phase is $\sim 320^{\circ} \mathrm{C}$ (note that these feldspars are essentially An-free). Coherent exsolution would have begun below the coherent solvus for ordered feldspars. This curve was determined experimentally by Yund (1974), but only at $500^{\circ} \mathrm{C}$ and above. At this $T$, the ordered coherent solvus is $\sim 70^{\circ} \mathrm{C}$ below the strain-free solvus of Bachinski \& Müller (1971), and the Or-rich phase is $\sim \mathrm{Ab}_{20} \mathrm{Or}_{80}$. In more Or-rich bulk compositions, the $T$ separation of the solvi would be greater. For disordered feldspars, the coherent solvus at $400^{\circ} \mathrm{C}$ is about $120^{\circ} \mathrm{C}$ below the strain-free solvus (see Yund 1984, Fig. 1). If the solvus for ordered feldspars is similar, coherent exsolution and subsequent formation of dislocations took place in these feldspars of pegmatitic provenance below $\sim 200^{\circ} \mathrm{C}$. The only way to move these reactions to higher $T$ is to invoke the effect of $P$ on the solvus, about $200^{\circ} \mathrm{C} \mathrm{GPa}^{-1}$.

The samples of microcline cryptoperthite also provide evidence of low- $T$ fluid-feldspar reactions that might have occurred at the same time as the formation of the macroperthite veins. In both, replacive albite is growing out from semicoherent lamellae into microcline (Fig. 10f), presumably because of $\mathrm{Na}^{+} / \mathrm{K}^{+}$exchange via a fluid that entered the crystals along edge dislocations. Very similar replacive albitization is seen in the Shap feldspars (Lee et al. 1995, Fig. 7). In Perth, albite lamellae are commonly completely dissolved, leaving lenticular holes (Fig. 10c), and some albite lamellae have been replaced by micropore-rich irregular microcline. The key to the progression of these replacement reactions is the development of dislocations around the cryptoperthite lamellae (Figs. 1, 4, 11). Prior to exsolution, or where small lamellae remain coherent, crystals remain impermeable and unreactive. These dislocation networks are discussed more fully in the next section.

Our study of the two pegmatitic feldspars shows clearly their textural heterogeneity and complexity. They contain dislocations and subgrain boundaries, which would be considerably more reactive in dissolution than pristine feldspar, and their reactivity would evolve as more highly strained parts of the structure dissolved. They contain sites that have been etched naturally by aqueous solutions below $200^{\circ} \mathrm{C}$ before entering the weathering realm. Bearing in mind that even in a lengthy dissolution-type experiment (usually up to 1 year), only a very small volume of feldspar is actually removed, the difficulty of obtaining generically applicable rates of dissolution from studies of such feldspars is obvious.

\section{WEATHERING OF THE SHAP FELDSPARS}

The full inventory of microtextures in a $100 \mu \mathrm{m}$ fragment of alkali feldspar from the Shap granite is shown in Figure 1, based on the SEM and TEM work of Lee et al. (1995) and Lee \& Parsons (1997a, b). Its features can be matched in many feldspars from granites and felsic gneisses, although the coarseness of the strain-controlled film lamellae is variable, as is the proportion of deuterically recrystallized material. In many cases, alkali feldspar from granitic rocks is less sodic in bulk composition than at Shap, which changes the proportions of the phases. The cross-cutting veins of deuteric perthite contain albite more calcic $\left(\mathrm{An}_{9}\right)$ 

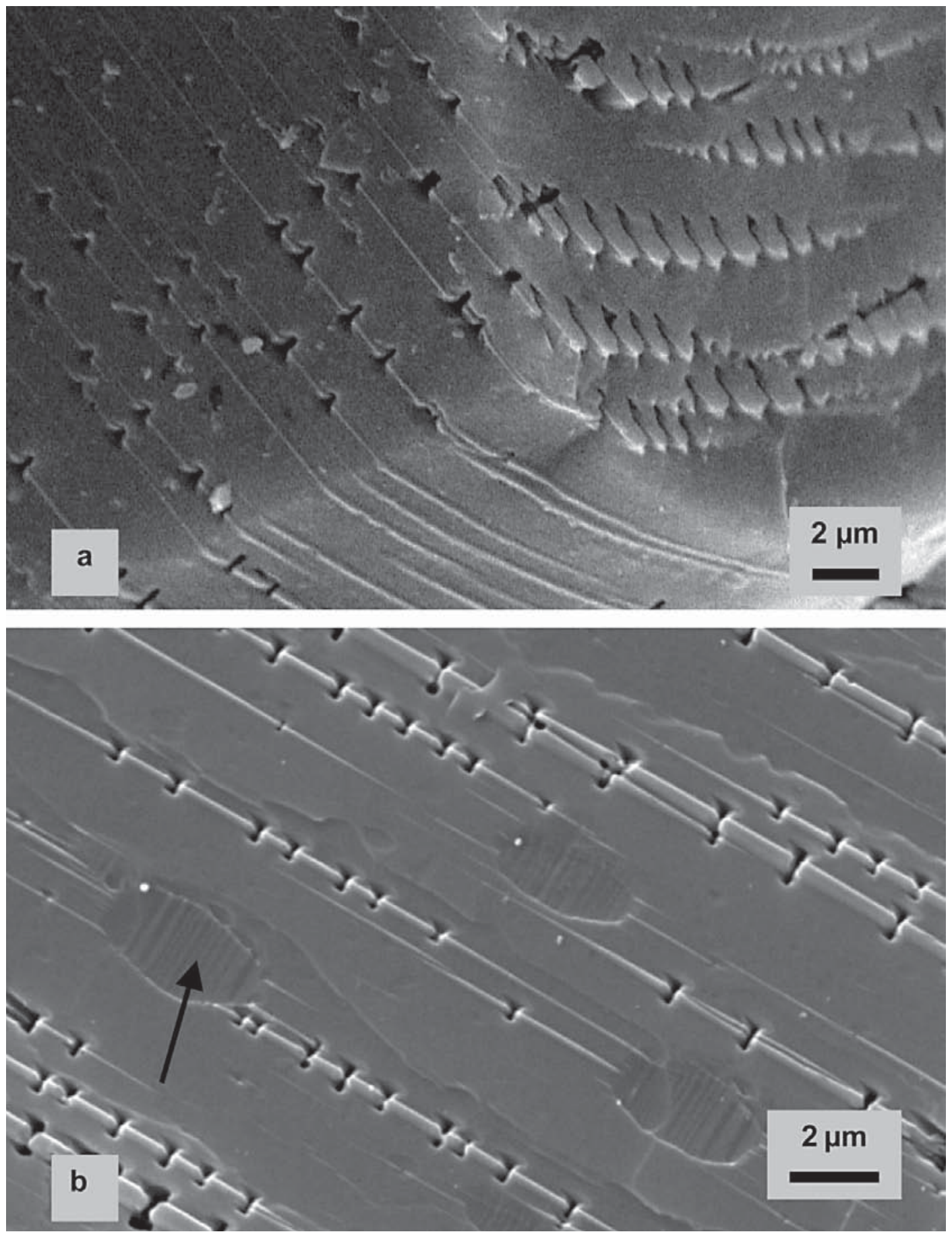

FIG. 11. Two SEM images of HF-etched cleavage fragments of plutonic alkali feldspar to illustrate the range of rock types in which cryptoperthitic lamellae of albite with misfit dislocations can be found. (a) From the 1 Ma Tato granite pluton, Nanga Parbat (sample provided by Nigel Harris). (b) From 530-Ma granulite-facies gneiss, Brattstrand Bluffs, Antarctica (Cayzer 2002). The oval bodies (example arrowed) are albite exsolved before the formation of the lamellar albite with dislocations. The banding in the oval blebs is Albite twinning. 
than albite elsewhere in the crystals, and may represent non-isochemical replacement. We do not know if the pure replacive albite is a universal feature of feldspars from granites.

The dislocation loops surrounding the semicoherent film lamellae, and the subgrain boundaries and associated micropores in the deuterically coarsened areas, are particularly important in weathering of the Shap feldspars. Reports of dislocations related to exsolution microtextures in alkali feldspars based on TEM were rare (Brown \& Parsons 1984b), but Waldron et al. (1994) used HF to etch cleavage fragments of Shap feldspar and found abundant etch pits representing the outcrop of dislocations (Fig. 4). We have since found them in many examples of plutonic feldspars, in rocks ranging from the youngest known plutonic granite (Fig. 11a), the 1 Ma Tato pluton from Nanga Parbat in the northwestern Himalayas (Zeitler et al. 1993), to Precambrian granulite-facies gneisses from Antarctica (Fig. 11b, Cayzer 2002). Figure 10e shows examples from a pegmatitic occurrence. Fitz Gerald et al. (2006) found that even in apparently "fresh" parts of the feldspar grains from Shap, natural intracrystal dissolution of feldspar immediately surrounding dislocations had occurred in deuteric fluids, giving rise to a network of "nanotunnels" only a few nm in diameter (Fig. 12). We have found similar tunnels in feldspars from granulitefacies gneisses and charnockites, so that fluids were active even in these ostensibly "dry" rocks.

The importance of the dislocations and deuterically coarsened areas in weathering cannot be overstated, as illustrated by Lee \& Parsons (1995) and Lee et al. (1998). The former dissolve rapidly relative to the normal structure because of additional free energy in the dislocation cores and strain energy in the distorted structure around them. Volumes with heterogeneous elastic coherency-induced strain also dissolve more rapidly than the unstrained structure, so that grooves form at the outcrop of albite lamellae on cleavage surfaces. Although the absolute rates of dissolution of albite and orthoclase are similar in acid solutions far from equilibrium, homogeneous and heterogeneous strain in the volumetrically subordinate albite lamellae may lead to appreciably more rapid dissolution of albite in perthitic alkali feldspars. Deuterically coarsened feldspar dissolves very rapidly, presumably because of free energy in incoherent subgrain boundaries (Worden et al. 1990, Walker et al. 1995). As Velbel (1989) and Blum \& Lasaga (1987) have stressed, although reaction rates slow as solutions approach equilibrium (as chemical affinity decreases), the relative effect of defects increases close to equilibrium. In soil waters such as those in the peat at Shap, we can expect solutions to be close to equilibrium with the silicate and organic phases. Hochella \& Banfield (1995) coined the term "internal zone" to describe weathering reactions in confined spaces. As we show in the final section, this concept is even more relevant in pore-waters in sedimentary basins, which may spend tens or hundreds of millions of years close to a metastable equilibrium with the solids.

The climate at Shap is very wet $(\sim 2.5 \mathrm{~m}$ of rainfall per annum) and cool (rarely below $-10^{\circ} \mathrm{C}$, rarely above $+20^{\circ} \mathrm{C}$ ). Water in the permanently water-logged peat soils is acid, $\mathrm{pH}$ 3.4. Although the detailed history of weathering of any part of the land surface is unknowable, we can say that glaciers retreated from the area between 15,000 and 10,000 years ago, so no surfaces are geologically old, and soils are unlikely to be much more than 10,000 years old. Figure 13 shows the lightly weathered surfaces of fragments of alkali feldspar from rain-washed surface gravels in the vicinity of exposures of the Shap granite. These are the naturally etched equivalents of the HF-etched surface in Figure 4. The etch pits at the edges of albite lamellae in Figure 13a are deep and relatively angular, but the albite and orthoclase lamellae themselves are relatively smooth, except at the edges, where faint grooves mark regions of heterogeneous elastic strain. Figure 13b shows etch pits intersecting in two directions in the Murchison

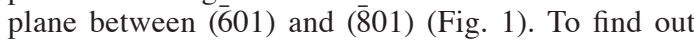
how deeply the etch-pit networks extend, we impregnated weathered grains in vacuo with Araldite resin, allowed it to cure, and then dissolved all feldspar in concentrated HF acid. This produced remarkable fabriclike casts (Fig. 14) showing that rectangular networks of etch pits form honeycomb networks extending at least $70 \mu \mathrm{m}$ under the surface of weathered alkali feldspars. Parsons et al. (1998) and Smith et al. (1999) proposed that these sub- $\mu \mathrm{m}$ diameter tubes would provide perfect reactors for the origin of life on Earth.

As weathering progresses, the etch pits become important in mechanical degradation of the feldspar surface. Figures $15 \mathrm{a}-\mathrm{c}$ show the uncleaned surfaces of feldspar fragments from grus, a gravel made up at Shap largely of alkali feldspar, plagioclase and quartz fragments in a peat matrix. On the surface shown, perthitic albite has almost completely dissolved, and the residual intervening orthoclase is breaking away in thin flakes. Compared with the very smooth surface of the feldspar grain as it is released from its parent rock, there is an enormous increase in potential reactive surface-area. Figure $15 \mathrm{~b}$ shows that dissolution rate is strongly influenced by variations in microtexture. An original igneous growth-zone (see Fig. 1) slightly richer in anorthite and celsian components than the surrounding feldspar (Lee \& Parsons 1997b) contains exsolution lamellae that are of finer-scale than in the bulk of the feldspar, because of coupling of $\mathrm{Ca}^{2+}$ and $\mathrm{Ba}^{2+}$ with framework $\mathrm{Al}^{3+}$. Because of their small size, they have not developed dislocations, and little dissolution has occurred in the zone. It is commonly possible to see zoning like this with the naked eye on weathered alkali feldspars, although it may not be visible on fresh surfaces. Regions with deuteric coarsening (Fig. 15c) dissolve deeply, showing the irregular shape of constituent subgrains. 
Figure $15 d$ is the surface of a Shap phenocryst from an ice-sculpted exposure of the granite. On such surfaces, the large phenocrysts generally stand out a few $\mathrm{mm}$ above the rest of the rock. The natural surface of the crystal is at the top of the image and nearly parallel to the viewing direction. It has a surface layer of smectite, forming hemispherical bodies. The surface facing the viewer was made by fracturing the phenocryst. The albite lamellae have almost completely dissolved; remarkably, this selective dissolution extends as much as $15 \mathrm{~mm}$ into some phenocrysts, which are semi-hollow structures resembling toast-racks. Since the exposure is $<15,000$ years old, albite surfaces have retreated at $>1$ $\mu \mathrm{m} \mathrm{yr}^{-1}$. The outer surface of the orthoclase grain also must be dissolving, albeit much more slowly, but the albite surface must be lowering at $>1 \mu \mathrm{m} \mathrm{yr}^{-1}$ with respect to the original surface. This is much faster than predicted by the dissolution experiments described in the next section. It is all the more remarkable because the reactive sites (i.e., the dislocation outcrops) are at the bottom of very deep but narrow "canyons", and the grain is very unlikely to have been continuously bathed in fresh acid for all of its weathering history.

The images discussed above (Figs. 13-15) show conclusively that in Nature, defects (mainly edge dislocations in lamellar perthite and subgrain boundaries in patch perthite) are crucial to the way alkali feldspars dissolve and degrade mechanically. We have seen similar features in alkali feldspars from many sources, including clastic grains in sedimentary rocks (see the final section). In general, the albite phase of perthite grains dissolves relatively rapidly, leaving a fragile skeleton of K-feldspar. The reason for this is discussed in the next section.

\section{EXPERIMENTAL DISSOLUTION OF FELDSPARS}

Background information in this section comes mostly from the review of Blum (1994). During experiments, dissolution of feldspars in aqueous solutions

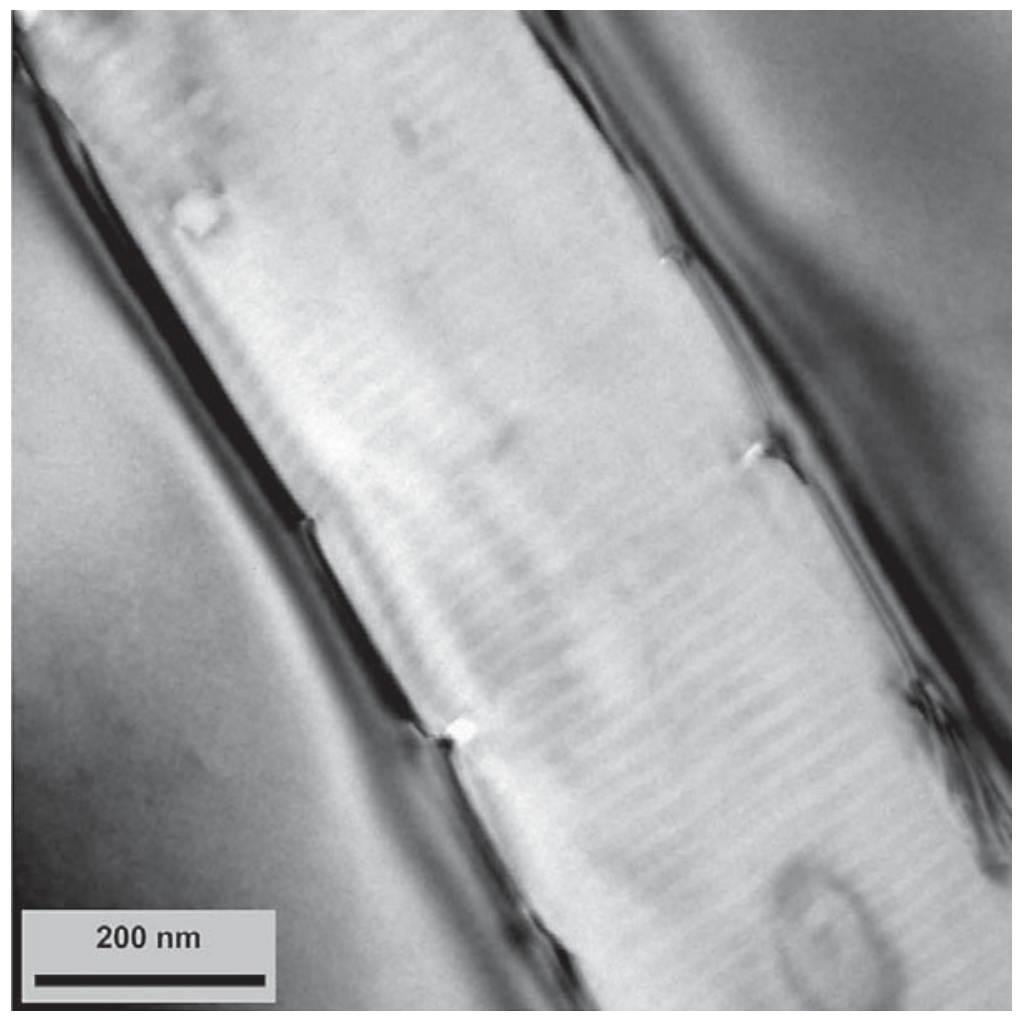

FIG. 12. Bright-field TEM image of Pericline-twinned albite lamella in a Shap feldspar viewed parallel to $b^{*}$. The lamella is straddled by pairs of minute "nanotunnels" that have formed by natural etching of dislocations by fluids in the cooling rock. The image is of part of a crystal that appears perfectly "fresh" in an optical microscope. From Fitz Gerald et al. (2006). 

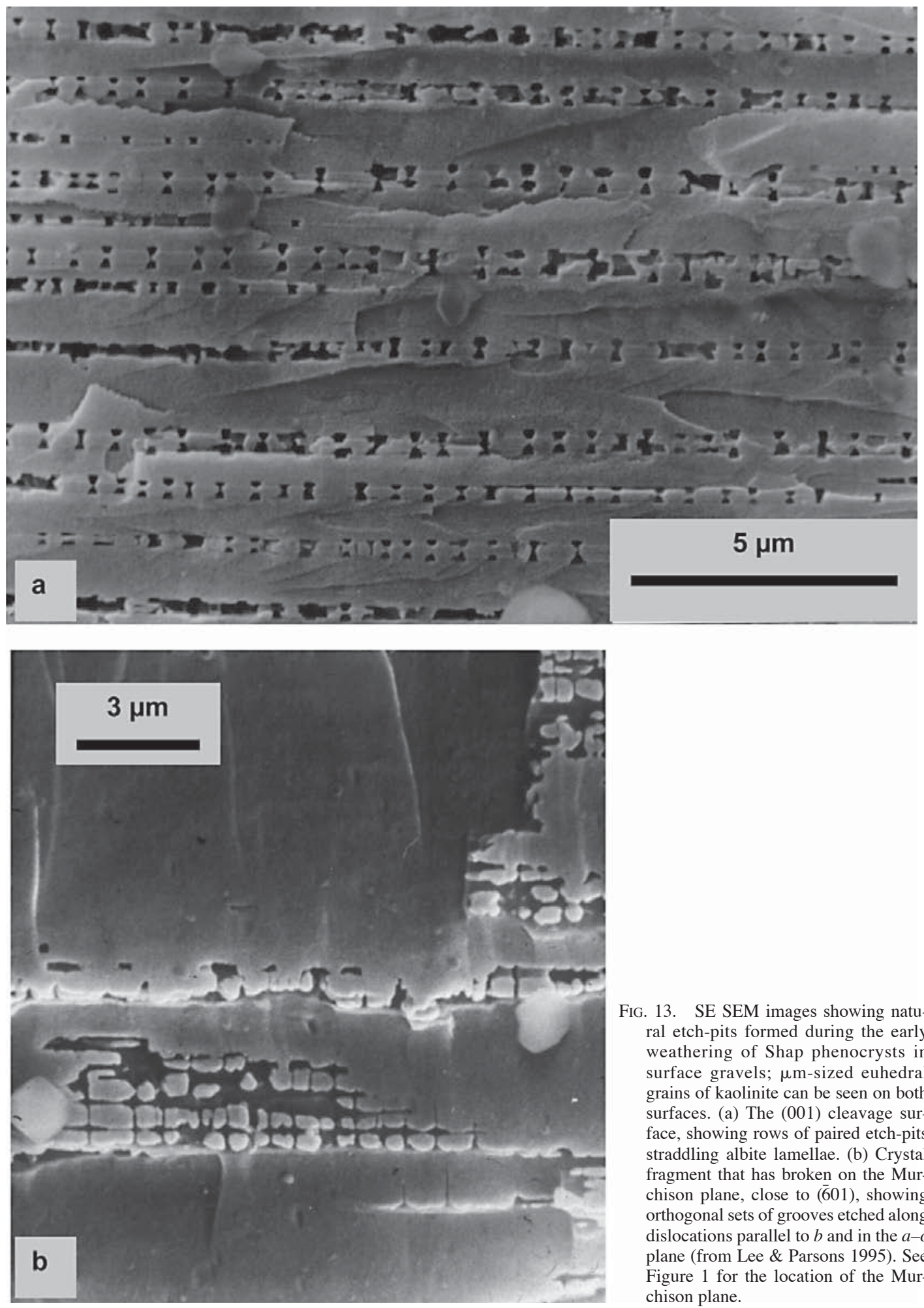

FIG. 13. SE SEM images showing natural etch-pits formed during the early weathering of Shap phenocrysts in surface gravels; $\mu \mathrm{m}$-sized euhedral grains of kaolinite can be seen on both surfaces. (a) The (001) cleavage surface, showing rows of paired etch-pits straddling albite lamellae. (b) Crystal fragment that has broken on the Murchison plane, close to ( $\overline{6} 01)$, showing orthogonal sets of grooves etched along dislocations parallel to $b$ and in the $a-c$ plane (from Lee \& Parsons 1995). See Figure 1 for the location of the Murchison plane. 
is initially relatively rapid, but then it declines over a period of several tens or hundreds of hours to a "steadystate" rate. The reason for the initial high rate is not certain, but small particles adhering after grinding of the starting material or defects induced by grinding itself were suggested by Holdren \& Berner (1979). Murphy (1989) compared the dissolution rates of Eifel sanidine crystals that had been deformed in a Griggs apparatus (a piston-cylinder device modified for studies of deformation) with undeformed material and found little difference, perhaps because both samples were finely crushed before the dissolution work. Figure 16 shows a compilation of steady-state rates of dissolution in albite and $\mathrm{K}$-feldspar at a range of $\mathrm{pH}$ near $25^{\circ} \mathrm{C}$ provided by Blum, with the addition of data for Shap cleavage fragments and an Eifel sanidine from Lee $e t$ al. (1998). Although dissolution rates in acid solutions of albite and K-feldspar can be seen to be similar; they both vary internally by more than an order of magnitude at any $\mathrm{pH}$. It is difficult to unravel the reasons for this large variation; possible factors were reviewed by Blum. They include: catalytic or inhibiting effects of organic and inorganic solutes, including $\mathrm{pH}$ buffers, saturation state of the solution, defects in the feldspar, compositional variation in the feldspars, different preparatory treatment of starting materials, different ways of measuring surface-areas, and precipitation of secondary phases. Blum also noted that comparison of datasets can be difficult because mineral names inconsistent with the chemical composition are often used.

Surface roughness, $\lambda$, of reacting particles, defined as the ratio of surface area obtained by the BET gasadsorption method to the geometrical surface-area calculated from particle size, is an important variable in dissolution studies, in which dissolution rates are normalized to surface area. Hodson et al. (1997) investigated the surface roughness of fragments of ten samples of feldspar crushed to 125-63 $\mu \mathrm{m}$, including Perth and Keystone, sanidine from Eifel, and phenocrysts from two variants of the Shap granite. Surprisingly, all these samples had similar values of $\lambda$, ranging from 5.16 (a light-colored variant of Shap) to 6.76 for Keystone. The Eifel sanidine gave 5.40. Very turbid feldspars from the Klokken syenite gave 22.0. Hodson et al. concluded that the crystal microtexture influences $\lambda$ by controlling the way in which feldspar grains break during grinding, which affects the frequency of steps on the grain surface. The apparent roughness of the Eifel sanidine particles is puzzling, since the fragments look perfectly smooth in the SEM; Hodson et al. suggested that the geometrical surface-area of the Eifel fragments is higher than estimated because the sieved fragments have a platy, rather than equidimensional morphology. This platiness could reduce $\lambda$ to values near to 1 . However, we consider that there are experimental problems with the BET method applied to microtexturally complex

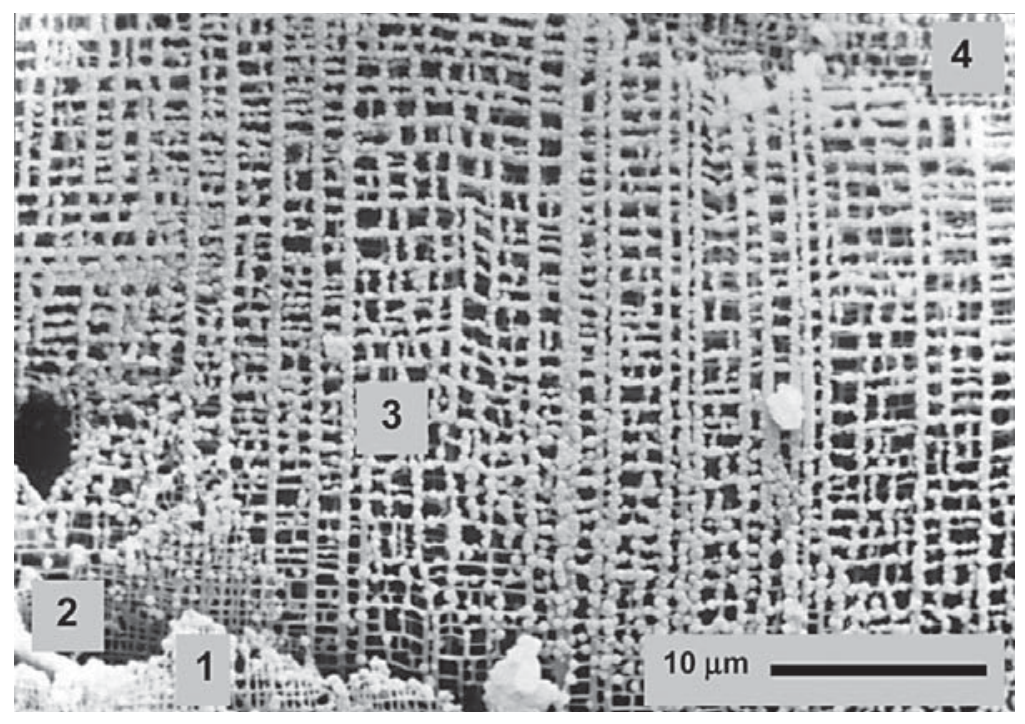

FIG. 14. SE SEM image of a resin cast of intersecting etch tubes in a naturally weathered Shap alkali feldspar phenocryst. The feldspar has been completely dissolved in HF, leaving slightly flexible casts resembling dish-cloth fabric. There are four cloths in this image, two small upper fragments ( 1 and 2$)$ at the bottom left, a large cloth forming most of the image (3), and a lower cloth at top right (4). Each cloth is a cast of etched dislocations on the surface of an albite lamella in the Murchison plane, as in Figure 13b. These etch-pit honeycombs provide plausible protective reactors for the origin of life (Parsons et al. 1998). 

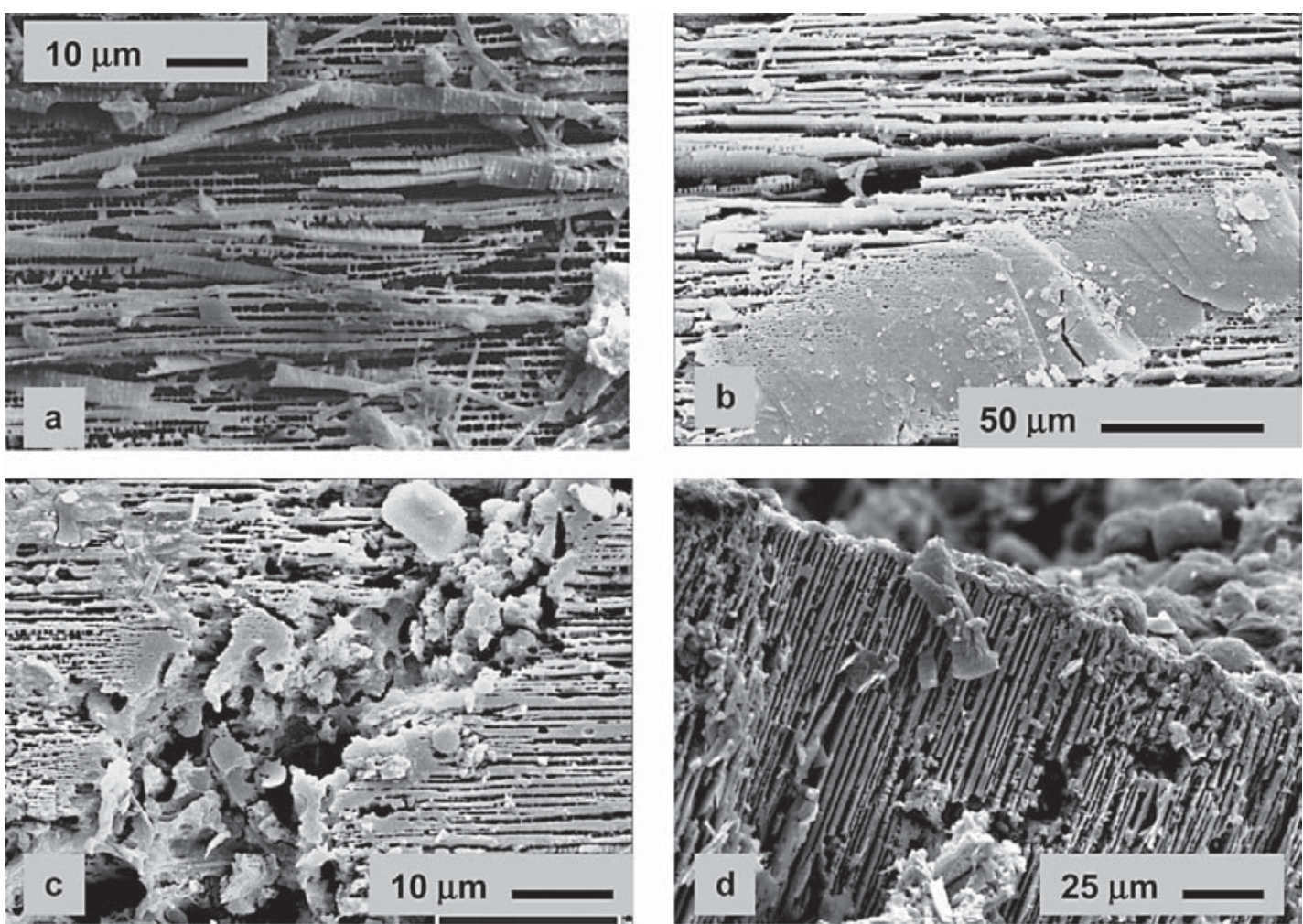

FIG. 15. SE SEM images of (001) cleavage surfaces of Shap feldspars showing more advanced weathering than in Figure 13. The grains have not been ultrasonically cleaned. (a) Albite has largely dissolved, leaving wafers of orthoclase that are beginning to fragment mechanically. Relics of dislocation etch-pits are still visible. From Lee et al. (1998). (b) Relatively featureless igneous growth-zone (bottom) that has exsolved to form coherent cryptoperthite without dislocations and is therefore more resistant to weathering than the surrounding microperthite, with its misfit dislocations. (c) Band of patch perthite, running from top right to bottom left, which has dissolved relatively rapidly. A stereopair of this image is given in Lee et al. (1998). (d) Interior of a phenocryst removed from an exposure of weathered granite at Shap. The surface facing the reader has been produced by laboratory fracturing. The natural surface is visible at the top right and is covered by globular masses of smectite. The wafer-like structure, from which albite has been removed during weathering, extends in some cases more than $15 \mathrm{~mm}$ into the large phenocrysts (micrograph by Amos Aikman).

silicates; for example, $\lambda$ measured by this method by Lee et al. (1998, see next section) appears to increase threefold during the dissolution experiments on fresh Shap cleavage fragments. It is difficult to envisage the physical reality behind this apparent change. See also Hodson et al. (1997) and Hodson (1998) on this subject.

The micrographs of naturally weathered feldspars (Figs. 13-15) show that in the field, microtexture is the pre-eminent control of dissolution and destruction of alkali feldspars, but this has not been shown to be the case in any experimental studies, and the literature contains numerous images (mostly SEM images at relatively low magnification, it must be said) illustrating the smooth surfaces of experimentally dissolved alkali feldspars. The data of Lee et al. (1998) are significant because all three samples were subjected to the same laboratory methods and had known microtextures: Eifel sanidine, almost devoid of defects; fresh, unweathered Shap feldspar, and naturally weathered Shap feldspar. The philosophy here was that the sanidine fragments would have substantially fewer microtexture-related reactive sites than the weathered Shap sample, which in turn would have a lower density of highly reactive sites than the freshly cleaved Shap fragments, because they had been "used up" by natural weathering. The experiments were carried out in a flow-through apparatus in a $\mathrm{pH} 2 \mathrm{HCl}$ solution. Normalized to initial surface-area (BET method), the three samples were found to have extremely similar steady-state far-from-equilibrium rates of dissolution, 1.24, 1.61 and $2.83 \times 10^{-15}$ moles feldspar $\mathrm{cm}^{2} \mathrm{~s}^{-1}$, respectively (Fig. 16). These vary in 
the expected direction but by only a factor of $\sim 2$, much less than the overall order-of-magnitude range shown by other data on Figure 16. In addition, using a conventional SEM and gold-coated samples (like previous investigators), Lee et al. could see no sign of accelerated dissolution around albite lamellae and dislocation outcrops analogous to Figure 13a. On the face of it, the role of microtexture in rates of laboratory dissolution seems to be very much less than in nature.

It is, however, important to introduce some spatial realism into what actually happens during an experiment; the commonly used units to express rate of dissolution $\left(10^{-\mathrm{n}}\right.$ moles feldspar $\left.\mathrm{cm}^{2} \mathrm{~s}^{-1}\right)$ are hardly user-friendly. In fact, translated into easily visualized units, the surface of a $100 \mu \mathrm{m}$ cube (roughly the particle size used in the experiments) of Eifel sanidine or weathered Shap feldspar in our $\mathrm{pH} 2$ experiments would lose $\sim 3 \mathrm{~nm}$ of surface in one year if it dissolved evenly! Only extremely high-resolution methods are likely to reveal grain-surface modification attributable to dissolution. In neutral solutions, surface loss represents a layer fractions of a unit-cell thick. Using ten different samples of feldspar (including Shap and Eifel), Hodson et al. (1997) showed that angular corners and surface steps on cleavage fragments influence rates of experimental dissolution more than do internal microtextural features such as microporosity, again in apparent contrast to field relationships. However, using a controlled-pressure SEM and uncoated samples, Lee et al. (1998) were able to image etched perthite lamellae and dislocation outcrops on the products of laboratory dissolution, and they also obtained the Atomic Force Microscope (AFM) images shown as Figure 17. It is clear that provided methods of adequate resolution are used, laboratory dissolution can be shown to occur at sites that dominate dissolution in the field, but the contribution of these sites to experimental dissolution is subordinate to the ephemeral contribution of grain edges and surface irregularities. Major microtextural sites of dissolution in natural weathering extend throughout the crystals and are not ephemeral features "used up" in the initial stages of dissolution. They become particularly important when a crystal moves into a regime where the crystals are close to equilibrium with the solutions, as in the Shap peat soils and also, as we shall see in the final section, in sedimentary basins.

In the weathered samples illustrated (Fig. 15) and elsewhere, and in sediments during diagenesis, a common pattern of dissolution is that albite dissolves before K-feldspar, although dissolution rates are similar. Blum (1994, p. 606) commented that the reasons for the rapid dissolution of plagioclase are uncertain, but that it may be related to the fact that solute concentrations are higher in natural weathering than in normal dissolution-type experiments. In our view, the key relationship can be deduced from the very important experiments of Orville (1963), at $P_{\text {total }}$ of 0.2 GPa between 700 and $500^{\circ} \mathrm{C}$, on the distribution of $\mathrm{Na}^{+}$and $\mathrm{K}^{+}$between $2 \mathrm{M}$ chloride solutions and alkali feldspars. These show that brines in equilibrium with two feldspars (an Ab- and an Or-rich feldspar on the feldspar solvus) have fixed $\mathrm{Na} /(\mathrm{Na}+\mathrm{K})$ at any $T$ irrespective of the proportions of the two feldspars. The fluid becomes progressively more sodic with decreasing $T$. Orville showed that his data are relevant to geothermal systems at Wairaki (New Zealand) and Yellowstone (Wyoming) down to $200^{\circ}$ C. Kastner (1971) and Kastner \& Siever (1979) extrapolated Orville's data to low $T$ and showed that at

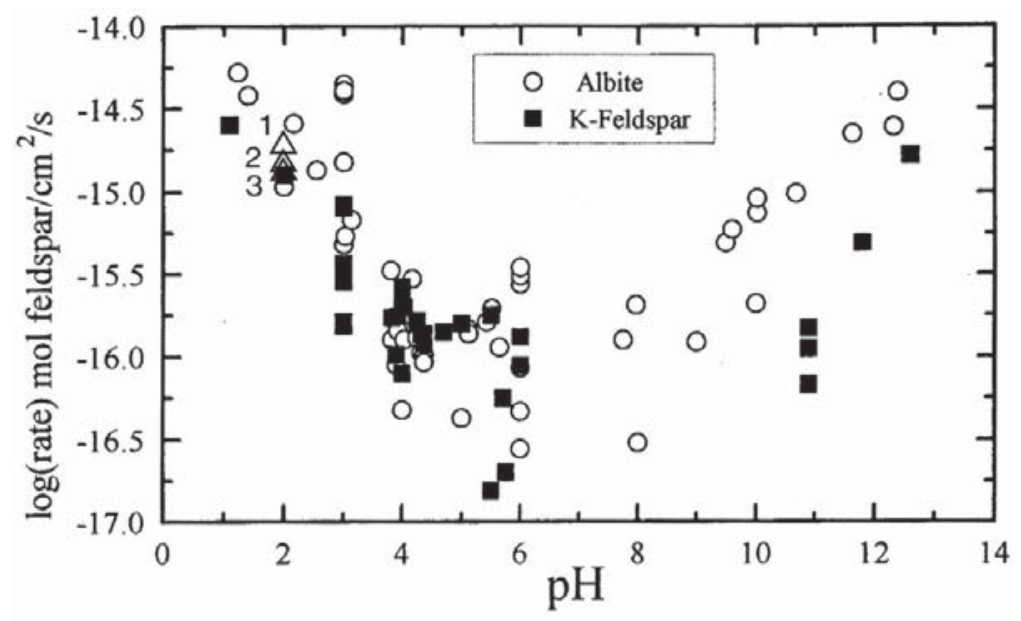

FIG. 16. Compilation of experimental data on steady-state rate of dissolution for albite and K-feldspar, from Blum (1994). Triangles are data for unweathered (1) and weathered (2) Shap alkali feldspar, and Eifel sanidine (3), added from Lee et al. (1998). 
$100^{\circ} \mathrm{C}, \mathrm{Na} /(\mathrm{Na}+\mathrm{K})$ would be $\sim 0.97$, close to the value for seawater, and Giggenbach (1988) reviewed many lines of evidence including active geothermal systems supporting this deduction. Pressure has a minor effect, but Lagache and coworkers (reviewed by Lagache 1984) showed that $\mathrm{Na} /(\mathrm{Na}+\mathrm{K})$ in the fluid is sensitive to the anion in solution (at 500 and $600^{\circ} \mathrm{C}$ ), $\mathrm{F}^{-}$- and $\mathrm{CO}_{3}{ }^{2-}$-bearing fluids being very Na-rich, even at high $T$. Pore fluids in soils maintaining equilibrium with a perthitic feldspar will inevitably dissolve albite, and this situation will persist as dislocation-induced etch-pits work down perthite lamellae into the crystals. Thus surfaces like those in Figure 15 reflect feldspar-fluid equilibria rather than relative dissolution-kinetics. Nevertheless, bearing in mind the maximum 15,000 year age of the weathering shown in Figure 15d, and its $15 \mathrm{~mm}$ penetration into the crystal, it does seem that dissolution rates are considerably faster than implied by experiments (Fig. 16).

\section{REACTIONS IN SEDIMENTARY RockS}

The Shap granite was emplaced in Ordovician volcanic rocks in the lower Devonian ( $\mathrm{Rb}-\mathrm{Sr}$ age 394 $\pm 3 \mathrm{Ma}$, Wadge et al. 1978). About $2 \mathrm{~km}$ to the east of the outcrop of the intrusion, the Ordovician series is overlain by a Lower Carboniferous conglomerate that contains easily recognizable $\mathrm{cm}$-sized fragments of alkali feldspar transported from the exhumed Shap granite about 50 Ma after it crystallized. Diagenetic replacement reactions occurred during burial to $\sim 3 \mathrm{~km}$ at a $T$ reaching between 70 and $125^{\circ} \mathrm{C}$, inferred from apatite fission-tracks (Green 1986, Lewis et al. 1992). The bulk composition of the large fragments changed by texture-dependent replacement. Figure 18a shows an HF-etched cleavage surface on which most lamellae form shallow troughs rather the normal ridges of albite (Fig. 4). Only two lamellae stand out with positive relief. The TEM images (Fig. 18b) shows that all larger lamellae of albite have been replaced by microcline. Albite survived only in thin lamellae that do not reach grain surfaces or fractures. Diagenetic replacement reactions, like weathering, are microtexture-dependent.

We have recently (Parsons et al. 2005) studied detrital and authigenic alkali feldspars in the Fulmar Formation, a hydrocarbon reservoir-rock in the Upper Jurassic Humber group in the central North Sea, in which feldspar dissolution is a major source of secondary porosity. The rocks are fine- to medium-grained, shallow marine, heavily bioturbated arkosic sandstones, in which the solids contain up to 30 vol. $\%$ feldspar. The reservoir is overpressured and currently at $130^{\circ} \mathrm{C}$. Our material comes from five wells from measured depths ranging from 3273 to $5483 \mathrm{~m}$. Even though it has been suggested that the amount of detrital feldspar decreases with depth (Wilkinson \& Haszeldine 1996, Wilkinson et al. 1997), we found $>10$ vol. \% feldspar in deep wells. These feldspars have been close to metastable
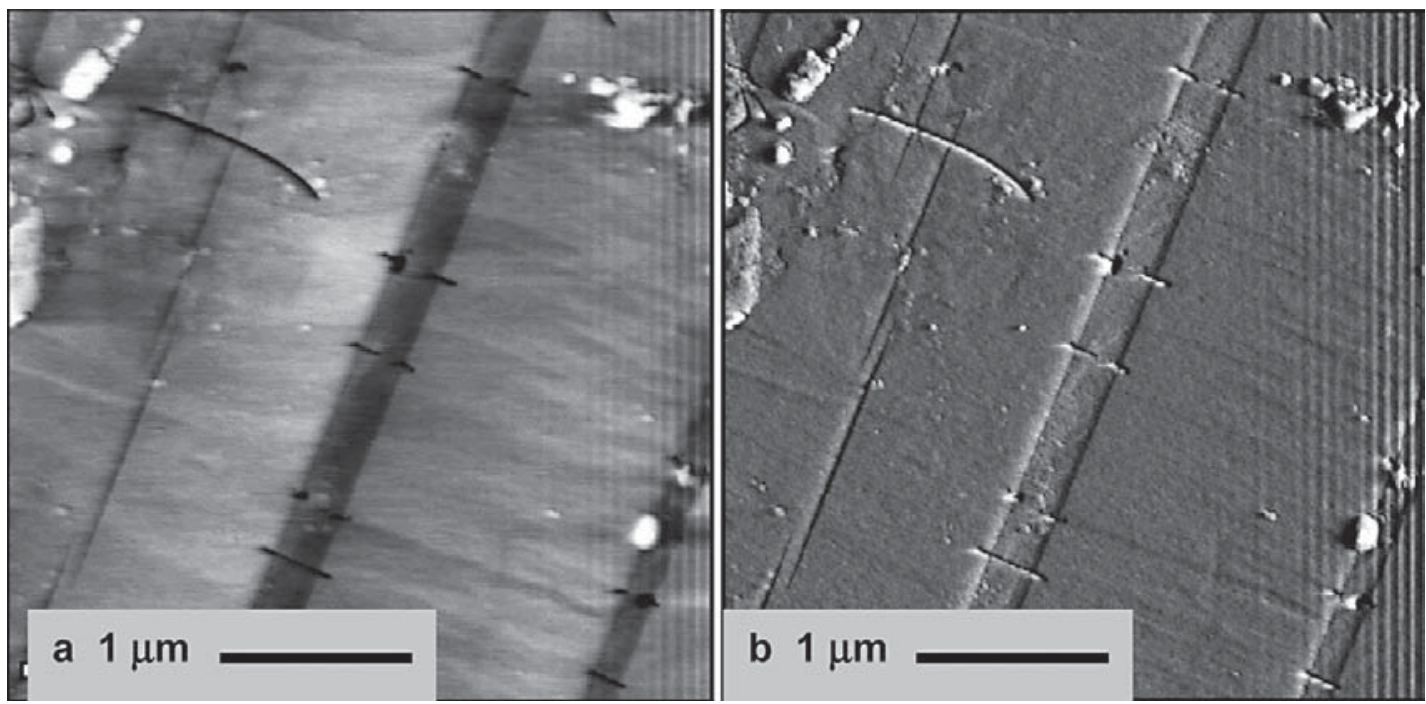

Fig. 17. Atomic Force Microscope images of the surfaces of unweathered Shap fragments exposed to $\mathrm{pH} 2 \mathrm{HCl}$ for $\sim 3300 \mathrm{~h}$ in a flow-through apparatus. The vertical banding at the right is an instrumental artifact. The image at the left shows raw data on surface topography. The dark gray albite lamellae are about $5 \mathrm{~nm}$ below the mid-gray surface of the orthoclase. Short black lines cutting across albite lamellae mark "pull-apart" defects associated with misfit dislocations (Fitz Gerald et al. 2006). The image on the right has been computer-processed to give an appearance of illumination from the right. Images obtained with the help of Fernando Camará and Peter Buseck at ASU. From Lee et al. (1998). 

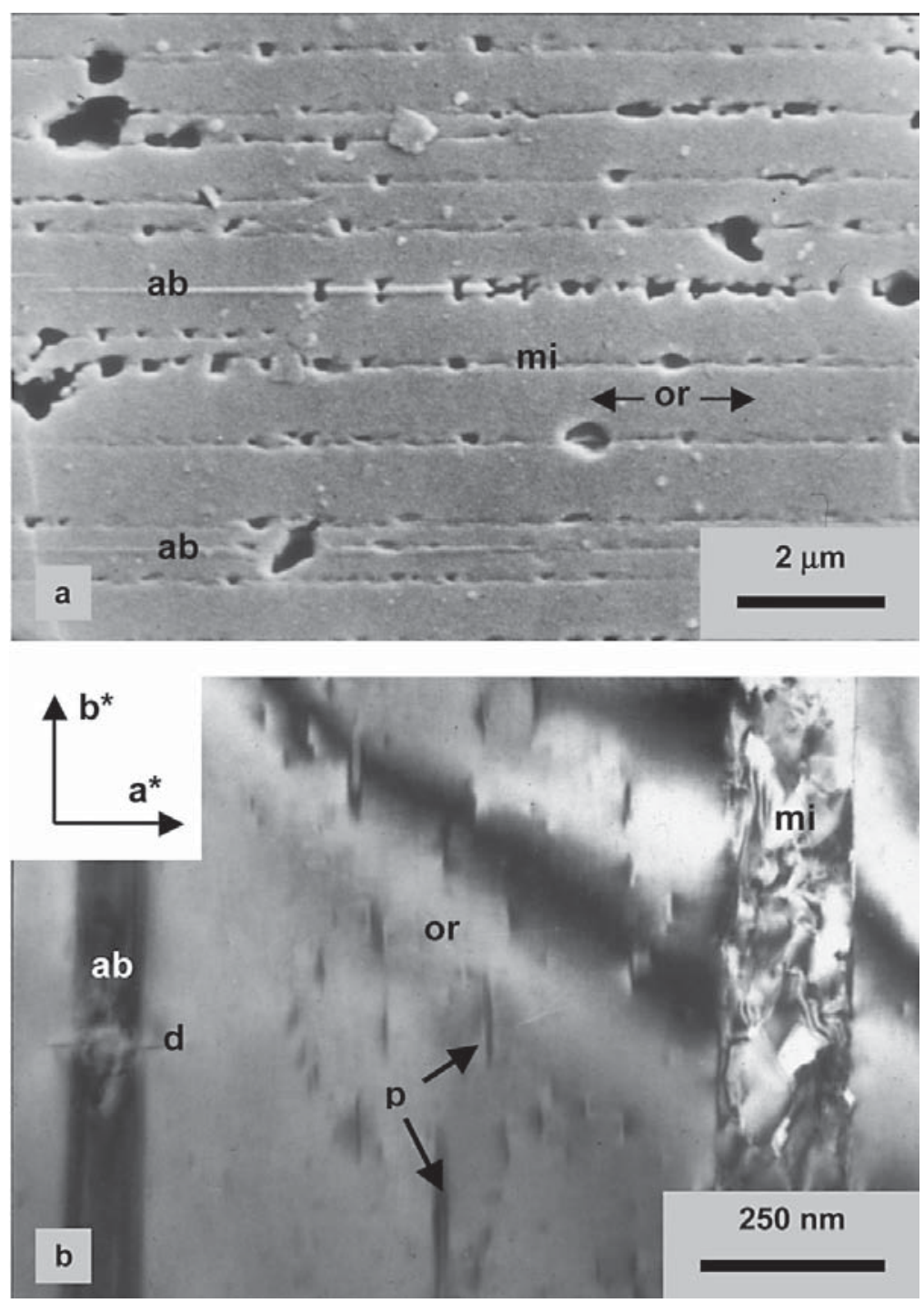

FIG. 18. Images of detrital fragments of alkali feldspars originating in the Lower Devonian Shap granite, but collected from an overlying Lower Carboniferous conglomerate. (a) The (001) surface of a fragment briefly etched with HF vapor. Lamellae form troughs in orthoclase (or) rather than the usual ridges (cf. Fig. 4) and are in fact formed of microcline (mi) that has replaced albite during diagenesis. Two lamellae (ab) are albite that has escaped replacement; they stand out with positive relief. (b) Bright-field TEM image of similar detrital feldspar. Thicker lamella at the right has been replaced by irregular microcline (mi), whereas thinner lamella at the left is albite (ab) that has escaped replacement, presumably because it was not connected to the grain surface or a suitable fracture. Note pair of tiny cracks on a dislocation (d). The tiny lenses (p) in the center of the micrograph are albite platelets formed late in igneous cooling of the orthoclase (or) matrix. From Lee \& Parsons (1998). 
equilibrium with aqueous fluids (likely to be changing both continuously and spasmodically in composition) or petroleum (or both), at progressively increasing $T$ and $P$, for $\sim 150 \mathrm{Ma}$. Their initial provenance could be from the UK, Norway and northern mainland Europe, and they may have come from reworked Devonian or Permo-Triassic sandstones (Stewart 1986).

Parsons et al. (2005) mainly employed BSE and CL imaging in an SEM to characterize alkali feldspars in polished sections, combined where necessary with semiquantitative energy-dispersion X-ray analysis. A source of ambiguity is that both authigenic albite and albite formed by replacement within the igneous or metamorphic parent rock of the detrital grains are non-cathodoluminescent. However, albite close to grain boundaries or fractures in detrital grains is likely to be authigenic. Albite (actually oligoclase in Shap) in cross-cutting veins of patch perthite (Figs. 1 and 6) is luminescent. Contrary to conventional sedimentological wisdom, the Fulmar reservoir rocks also contain a few $\%$ of detrital plagioclase from $\mathrm{Ab}_{100}$ to $\mathrm{Ab}_{82} \mathrm{An}_{18}$. Our TEM evidence shows that many grains are peristerite, suggesting that this infrequently reported microtexture may be common in the low-grade metamorphic rocks from which the detrital feldspars were ultimately derived (Lee et al. 2003).

Figure 19 shows that the provenance of the Fulmar alkali feldspars is diverse, and their response to dissolution, strongly dependent on microtexture. To avoid repetition, details are given in an extended caption. Parent rocks can be suggested for many detrital grains on the basis of distinctive microtextures. Preferential dissolution of lamellar perthitic albite, which we saw in soils, is common and clearly depends on the presence of edge dislocations. Weakened by partial dissolution, $\mathrm{K}$-feldspar with lamellar perthite may break during compaction. Grains of patch perthite dissolve easily, commonly leaving only skeletal relics. Feldspars that are either non-exsolved or have fully coherent intergrowths are resistant to dissolution. Grains of very Or-rich, optically homogeneous sanidine and fully coherent granulite-facies mesoperthite are relatively common in the Fulmar Formation. This is surprising, because subsolvus granites (like Shap) are abundant in the Caledonides surrounding the North Sea and should mainly yield feldspars with patch and semicoherent lamellar perthite microtextures. It seems that "microtextural winnowing" has occurred, so that the detrital alkali feldspar inventory is not a crustal average for the catchment. Thus secondary porosity, and hence reservoir quality, depends on provenance.

Authigenic overgrowths of K-feldspar of adularia habit and replacive albitization are common in the Fulmar. In some cases, the overgrowths remained stable throughout diagenesis (Fig. 19), whereas others have been partially corroded as conditions changed, even though surrounding detrital grains of K-feldspar remain unaffected. Again, the differences in diagenetic behavior between adjacent feldspar grains are controlled by microtexture. Although authigenic overgrowths of adularia habit commonly appear to be glass-clear single crystals in thin section, both studies of such overgrowths undertaken using TEM have shown that they are composed of sub- $\mu \mathrm{m}$ subgrains (Worden \& Rushton 1992, Lee \& Parsons 2003).

Feldspars in the Fulmar Formation record a sequence of dissolution and reprecipitation reactions involving both detrital and authigenic feldspars. It seems certain that the two-feldspar assemblage has been close to equilibrium with aqueous fluids in confined pore-spaces, the "internal zone" of Hochella \& Banfield (1995), for many tens of millions of years. Under these circumstances, relatively small changes in $T$ or fluid composition (or both) will be matched by small amounts of

FIG. 19. BSE SEM images of alkali feldspars in polished fragments of arkosic sandstone from the Fulmar Formation, showing a range of provenances and responses to dissolution leading to "microtextural winnowing". From Parsons et al. (2005). All scale bars are $50 \mu \mathrm{m}$. (a) Four grains of detrital alkali feldspar (light grey) of three microtextural types. Two featureless grains at left are very Or-rich sanidine, probably from an ultrapotassic volcanic protolith. Grains of this unusual type are relatively abundant in the Fulmar, because their lack of microtexture makes them resistant to dissolution. The central grain consists of patch perthite, and that at the right consists of fine-scale lamellar film perthite, probably both from a granitic protolith. (b) Lenticular microperthite, probably from a granite, with a euhedral overgrowth by K-feldspar of adularia habit. Several albite lamellae (dark grey) have dissolved, leaving lenticular voids (black). Compare with Figures 10c, 13 and 15. (c) Film microperthite, almost mesoperthite, possibly from a granite or granulite-facies gneiss, in which albite has partially dissolved. The weakened grain has broken during compaction, and this has been followed by a period of growth of authigenic K-feldspar that has partially lined a major fracture. The medium grey, porous grains forming a cement around much of the feldspar consist of dolomite. (d) A grain of patch perthite, probably from a granitic source. The grain has a partially resorbed K-feldspar overgrowth along its lower margin. (e) Highly corroded, largely skeletal grain of patch perthite. Grains of patch perthite are very commonly highly corroded, reflecting easy ingress of fluids, as in weathered examples (e.g., Fig. 15c). Dark area (ab) at bottom right of grain is probably diagenetic replacive albite. (f) The larger grain consists of flame perthite, a coherent microtexture characteristic of greenschist- or lower-amphibolite-facies metamorphic rocks. Two smaller light grey grains are volcanic sanidine, that at the right is Ba-rich and has an authigenic K-feldspar overgrowth. (g) Coherent mesoperthite from a granulite-facies gneiss. (h) Perthite with two stages of exsolution similar to the case in Figure 11b, and very probably from the granulite facies. Feldspars from granulite-facies rocks are disproportionately abundant in the Fulmar, because they are commonly fully coherent, or semicoherent with few dislocations, and therefore are resistant to dissolution and replacement. 

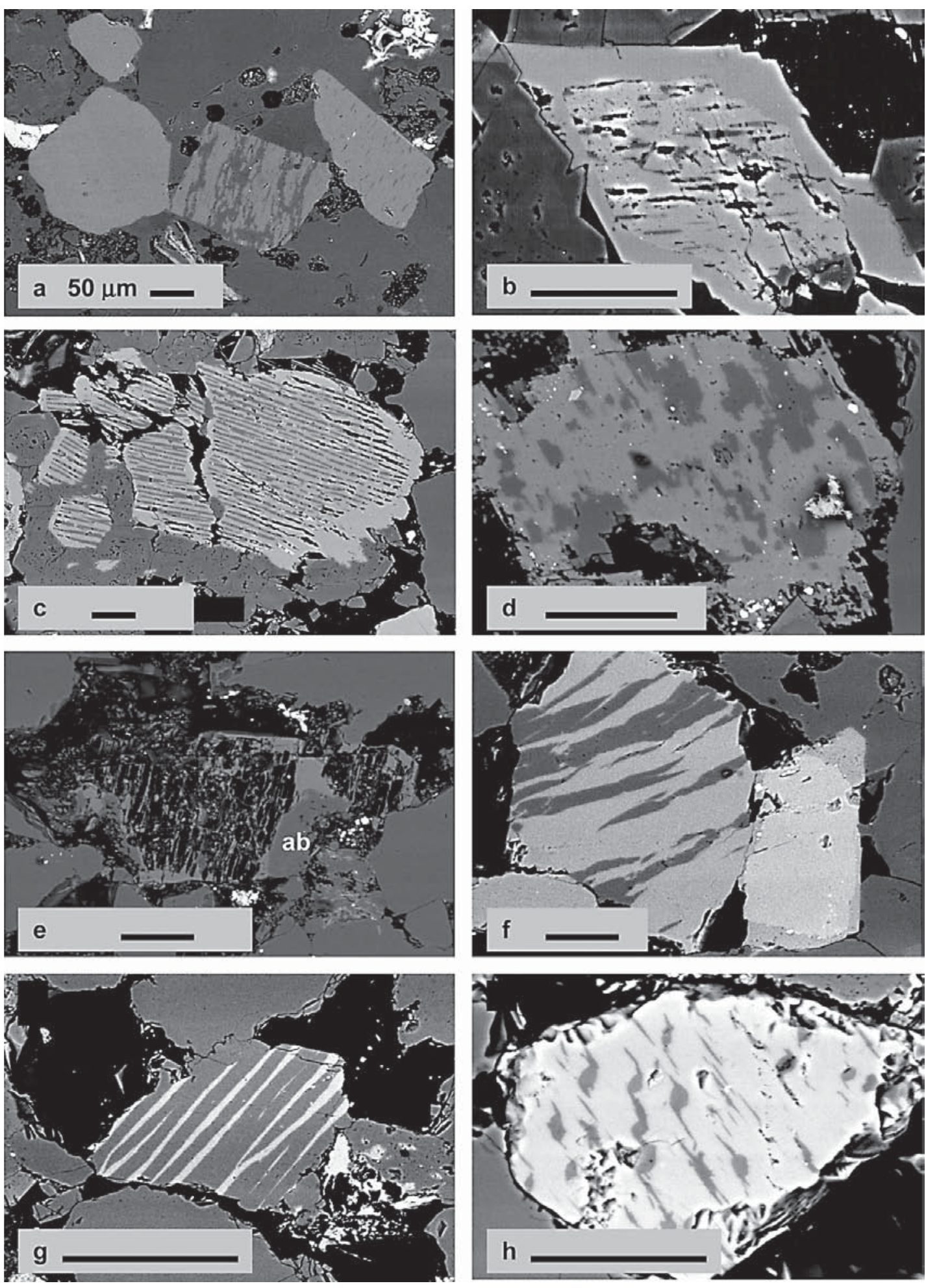
feldspar dissolution at the most reactive sites on grain surfaces or within skeletal or honeycombed feldspars. Most probably, reactions are dominated by the alkaliexchange equilibria involving two-feldspar assemblages described originally by Orville (1963; see preceding section). Where fluids are cool, for example in a sedimentary basin near the surface, albite will dissolve (in the Fulmar, partly from perthitic patches and semicoherent lamellae) to give solutions with high $\mathrm{Na} /(\mathrm{Na}$ $+\mathrm{K})$. As $T$ increases with burial, solutions become more potassic by precipitating albite and dissolving $\mathrm{K}$-feldspar, corresponding to the increasing "albitization" commonly seen in sedimentary basins (Milliken 1989). In the Fulmar, growth of authigenic K-feldspar follows dissolution and compaction (Fig. 19c), and is in some cases followed by resorption. Explanations for these events must await a systematic basin-wide study, but influxes of fluids with different anions are one possibility. The experimental data of Iiyama (1965) suggest that influxes of $\mathrm{CO}_{3}$-charged water would lead to dissolution of albite and precipitation of K-feldspar; return of a chloride-dominated solution would lead to resorption. None of these reactions involve large-scale mass transfer of $\mathrm{Si}$ and $\mathrm{Al}$; only local $\mathrm{Na} \rightarrow \mathrm{K}$ exchange is involved.

Our images show (Fig. 19) that it is microtexture, not only chemistry, that determines which alkali feldspar grains, and which parts of grains, participate in reactions in the Fulmar Formation. Figures 13 to 15 show that similar microtextures control the rate of dissolution and mechanical degradation of alkali feldspars during weathering. Figure 10 shows how microtexture has guided dissolution and replacement reactions with deuteric fluids in feldspars from pegmatites during cooling from igneous temperatures, as it has in feldspars from Shap (Figs. 1 and 6) and many other granites. Although, when they grow, alkali feldspars in granites are probably not unlike the gem-quality crystals that we described in early sections, by the time they reach the Earth's surface, they have a rich and informative inventory of microtextures that have evolved continuously to low temperatures (Figs. 4-6). Even gem-quality crystals exhibit microtextures at the TEM scale (Fig. 8), and some have unusual properties not seen in garden-variety samples. Many well-known gem-quality experimental materials vary at the source, and the exact sample used for a particular measurement of physical or chemical properties should be very carefully characterized. Minerals are most certainly not just chemical compounds.

\section{ACKNOWLEDGEMENTS}

We dedicate this paper to the anonymous reviewer of a mutual research-grant proposal who rejected it on the grounds that the work would "provide no data, only photographs". We gratefully acknowledge the efforts of many collaborators (coauthors of our papers in the references) whose beautiful photographs show so clearly how mineralogy and geochemistry are inextricably intertwined. We thank John Fitz Gerald for introducing the important phrase "garden-variety" to the world of real minerals. We thank the Natural Environment Research Council for a succession of grants, most recently GR3/10290 and currently NER/ A/S/2001/01099. The work on Fulmar was supported in part by Minor Service Contract 2200001839 from Shell UK Expro. An insightful review by Dan Kontak is gratefully acknowledged.

\section{REFERENCES}

Althaus, E. \& Tirtadinata, E. (1989): Dissolution of feldspar: the first step. In Water-Rock Interaction (D.L. Miles, ed.). Balkema, Rotterdam, The Netherlands.

Arnaud, N.O. \& Kelley, S.P. (1997): Argon behaviour in gem-quality orthoclase from Madagascar: experiments and some consequences for ${ }^{40} \mathrm{Ar} /{ }^{39} \mathrm{Ar}$ geochronology. Geochim. Cosmochim. Acta 61, 3227-3255.

BACHINSKI, S.W. \& MÜLleR, G. (1971): Experimental determinations of the microcline - low albite solvus. J. Petrol. 12, 329-356.

BANK, H. (1967): Hellbrauner klar durchsichtiger Alkalifeldspat von Volkesfeld/Eifel. Z. Dtsch. Ges.f. Edelsteinkunde 61, 50-53.

BERAN, A. (1986): A model of water allocation in alkali feldspar, derived from infrared-spectroscopic investigations. Phys. Chem. Minerals 13, 306-310.

BERNER, R.A. \& Holdren, G.R. (1977): Mechanism of feldspar weathering: some observational evidence. Geology 5, 369-372.

BERNER, R.A. \& HoldREn, G.R. (1979): Mechanism of feldspar weathering. II. Observations of feldspars from soils. Geochim. Cosmochim. Acta 43, 1173-1186.

Bernotat-Wulf, H., Bertelmann, D. \& Wondratschek, H. (1988): The annealing behaviour of Eifel sanidine (Volkesfeld). III. The influence of the sample surface and sample size on the order-disorder transformation rate. Neues Jahrb. Mineral., Monatsh., 504-515.

Bertelmann, D., FöRTSCh, E. \& WondratscheK, H. (1985): Zum Temperverhalten von Sanidinen: die Ausnahmerolle der Eifelsanidin-Megacrystal. Neues Jahrb. Mineral., Abh. 152, 123-141.

Bertelmann, D., Walther, J. \& WondratscheK, H. (1987): Annealing-induced inclusions and transformation behaviour of Eifel sanidines. Terra Cognita 7, 257-258.

BLuM, A.E. (1994): Feldspars in weathering. In Feldspars and their Reactions (I. Parsons, ed.). NATO Adv. Study Inst., Ser. C, 421. Kluwer Academic Publishers, Dordrecht, The Netherlands.

BLum, A.E. \& LASAGA, A.C. (1987): Monte Carlo simulations of surface reaction rate laws. In Aquatic Surface Chemis- 
try: Processes at the Particle - Water Interface (W. Stumm, ed.). J. Wiley \& Sons, New York, N.Y. (255-292).

Brown, W.L., BeCKer, S.M. \& PARsons, I. (1983): Cryptoperthites and cooling rate in a layered syenite pluton: a chemical and TEM study. Contrib. Mineral. Petrol. 82, 13-25.

BROWN, W.L. \& PARSONS, I. (1984a): Exsolution and coarsening mechanisms and kinetics in an ordered cryptoperthite series. Contrib. Mineral. Petrol. 86, 3-18.

BRown, W.L. \& PARSONS, I. (1984b): The nature of potassium feldspar, exsolution microtextures and development of dislocations as a function of composition in perthitic alkali feldspars. Contrib. Mineral. Petrol. 86, 335-341.

BRown, W.L. \& PARSONS, I. (1989): Alkali feldspars: ordering rates, phase transformations and behaviour diagrams for igneous rocks. Mineral. Mag. 53, 25-42.

Brown, W.L. \& Parsons, I. (1993): Storage and release of elastic strain energy: the driving force for low temperature reactivity and alteration of alkali feldspars. In Defects and Processes in the Solid State: Geoscience Applications: the McLaren Volume (J.N. Boland \& J. Fitz Gerald, eds.). Elsevier, Amsterdam, The Netherlands (267-290).

CARPEnTER, M.A. \& SALJE, E.K.H. (1994): Thermodynamics of nonconvergent cation ordering in minerals. III. Orderparameter coupling in potassium feldspar. Am. Mineral. 79, 1084-1098.

CAYZER, N. (2002): Feldspar Microtextures and the Cooling Histories of High-Grade Terrains. Ph.D. thesis, University of Edinburgh, Edinburgh, UK.

ČERNÝ, P. (1994): Evolution of feldspars in granitic pegmatites. In Feldspars and their Reactions (I. Parsons, ed.). NATO Adv. Study Inst., Ser. C, 421. Kluwer Academic Publishers, Dordrecht, The Netherlands.

CoomBs, D.S. (1954): Ferriferous orthoclase from Madagascar. Mineral. Mag. 30, 409-427.

Doremus, R.H. (1998): Comment on "Stationary and mobile hydrogen defects in potassium feldspar" by A.K. Kronenberg, R.A. Yund \& G.R. Rossman. Geochim. Cosmochim. Acta 62, 377-378.

EgGleton, R.A. \& BuSECK, P.R. (1980a): The orthoclase - microcline inversion: a high-resolution transmission electron microscope study and strain analysis. Contrib. Mineral. Petrol. 74, 123-133.

EgGleton, R.A. \& BusECK, P.R. (1980b): High resolution electron microscopy of feldspar weathering. Clays Clay Minerals 28, 173-178.

Evangelakakis, C., Kroll, H., Voll, G., Wenk, H., MeishENG, H. \& KOPCKE, J. (1993): Low temperature coherent exsolution in alkali feldspars from high-grade metamorphic rocks of Sri Lanka. Contrib. Mineral. Petrol. 114, 519-532.

Fenter, P., Teng, H., GeissbüHler, P., Hanchar, J.M., NAgy, K. \& Sturchio, N.C. (2000): Atomic-scale structure of the orthoclase (001) - water interface measured with high- resolution X-ray reflectivity. Geochim. Cosmochim. Acta 64, 3663-3673.

Fitz GeRALD, J.D. \& MCLAREN, A.C. (1982): The microstructures of microcline from some granitic rocks and pegmatites. Contrib. Mineral. Petrol. 80, 219-229.

Fitz Gerald, J.D., Parsons, I. \& Cayzer, N. (2006): Nanotunnels and pull-aparts: defects of exsolution lamellae in alkali feldspars. Am. Mineral. 91 (in press).

FolAND, K.A. (1974): ${ }^{40} \mathrm{Ar}$ diffusion in homogeneous orthoclase and an interpretation of Ar diffusion in K-feldspar. Geochim. Cosmochim. Acta 38, 151-166.

Foland, K.A. (1994): Argon diffusion in feldspars. In Feldspars and their Reactions (I. Parsons, ed.). NATO Adv. Study Inst., Ser. C, 421. Kluwer Academic Publishers, Dordrecht, The Netherlands.

Foland, K.A. \& Xu, Y.-P. (1990): Diffusion of ${ }^{40} \mathrm{Ar}$ and ${ }^{39} \mathrm{Ar}$ in irradiated orthoclase. Geochim. Cosmochim. Acta 54, 3147-3158.

GERING, E. (1985): Silizium/Aluminium-Ordnung und Kristallperfektion von Sanidinen. Dissertation, Universität Karlsruhe, Karlsruhe, Germany.

GigGEnBACH, W.F. (1988): Geothermal solute equilibria Derivation of Na-K-Mg-Ca geoindicator. Geochim. Cosmochim. Acta 52, 2729-2765

Ginibre, C., Wörner, G. \& KronZ, A. (2004): Structure and dynamics of the Laacher See magma chamber (Eifel, Germany) from major and trace element zoning in sanidine: a cathodoluminescence and electron microprobe study. $J$. Petrol. 45, 2197-2224.

GoldSMith, J. (1988): Enhanced Al/Si diffusion in $\mathrm{KAlSi}_{3} \mathrm{O}_{8}$ at high pressures: the effect of hydrogen. J. Geol. 96, 109-124.

Graham, C.M. \& ElPhick, S.C. (1990): A re-examination of the role of hydrogen in Al-Si interdiffusion in feldspars. Contrib. Mineral. Petrol. 104, 481-491.

Green, H.W. \& JunG, H. (2005): Fluids, faulting and flow. Elements 1, 31-37.

GREEN, P.F. (1986): On the thermotectonic evolution of northern England: evidence from fission track analysis. Geol. Mag. 123, 493-506.

Harris, M.J., SalJe, E.K.H., GÜtTler, B.K. \& Carpenter, M.A. (1989): Structural states of natural potassium feldspar. Phys. Chem. Minerals 16, 649-658.

Heinemann, S., Wirth, R. \& Dresen, G. (2001): Synthesis of feldspar bicrystals by direct bonding. Phys. Chem. Minerals 28, 685-692.

Hochella, M.F., JR. \& BANFIELD, J.F. (1995): Chemical wethering in silicates in nature: a microscopic perspective with theoretical considerations. In Chemical Weathering Rates of Silicate Minerals (A.F. White \& S.L. Brantley, eds.). Rev. Mineral. 31, 353-406. 
Hodson, M.E. (1998): Micropore surface area variation with grain size in unweathered alkali feldspars. Geochim. Cosmochim. Acta 62, 3429-3435.

Hodson, M.E., LeE, M.R. \& PARsons, I. (1997): Origins of the surface roughness of unweathered alkali feldspar grains. Geochim. Cosmochim. Acta 61, 3885-3896.

Hofmeister, A.M. \& Rossman, G.R. (1985): A model for the irradiative coloration of smokey feldspar and the inhibiting influence of water. Phys. Chem. Minerals 12, 324-332.

HoldREn, G.R., JR. \& BERnER, R.A. (1979): Mechanism of feldspar weathering. I. Experimental studies. Geochim. Cosmochim. Acta 43, 1161-1171.

Holdren, G.R., JR. \& SPEYeR, P.M. (1985): Reaction ratesurface area relationships during the early stages of weathering. I. Initial observations. Geochim. Cosmochim. Acta 49, 675-681.

HoldRen, G.R., JR. \& Speyer, P.M. (1987): Reaction rate - surface area relationships during the early stages of weathering. II. Data on eight additional feldspars. Geochim. Cosmochim. Acta 51, 2311-2318.

Hovis, G.L. (1988): Enthalpies and volumes related to K-Na mixing and $\mathrm{Al}-\mathrm{Si}$ order/disorder in alkali feldspars. $J$. Petrol. 29, 731-763.

Hütt, G., Jungner, H., Kujansuu, R. \& SaArnisto, M. (1993): OSL and TL dating of buried podsols and overlying sands in Ostrobothnia, western Finland. J. Quaternary Sci. 8, 125-132.

IIYAMA, J.T. (1965): Influence des anions sur les équilibres d'échange d'ions $\mathrm{Na}-\mathrm{K}$ dans les feldspaths alcalins à $600^{\circ} \mathrm{C}$ sous une pression de 1000 bars. Bull. Soc. fr. Minéral. Cristallogr. 88, 618-622.

KASTNER, M. (1971): Authigenic feldspars in carbonate rocks. Am. Mineral. 56, 1403-1440.

KASTNER, M. \& SiEVER, R. (1979): Low temperature feldspars in sedimentary rocks. Am. J. Sci. 279, 435-479.

Kimata, M., Saito, S., Shimizu, M., Iida, I. \& Tomoaki, M. (1996): Low-temperature crystal structures of orthoclase and sanidine. Neues Jahrb. Mineral., Abh. 171, 199-213.

Klein, J., Behrens, H., Göttlicher, J., Hafner, S.S. \& PentINGHAUS, H. (1996): An experimental study on incorporation of iron in alkali feldspar. Terra Nova (Abstr. Suppl.) 1, 34-35.

Kovacs, M.P. \& GandaIs, M. (1980): Transmission electron microscope study of experimentally deformed K-feldspar single crystals. Phys. Chem. Minerals 6, 61-76.

Kroll, H. \& KNITter, R. (1991): Al, Si exchange kinetics in sanidine and anorthoclase and modeling of rock cooling paths. Am. Mineral. 76, 928-941.

KronenberG, A.K., Yund, R.A. \& Rossman, G.R. (1996): Stationary and mobile hydrogen defects in potassium feldspar. Geochim. Cosmochim. Acta 60, 4075-4094.
Kronenberg, A.K., Yund, R.A. \& Rossman, G.R. (1998): Reply to the comment by Robert H. Doremus on "Stationary and mobile hydrogen defects in potassium feldspar". Geochim. Cosmochim. Acta 62, 379-382.

LACROIX, A. (1912): Note préliminaire sur quelques minéraux de Madagascar dont plusieurs peuvent être utilisés comme gemmes. C. R. Acad. Sci. Paris 155, 672-677.

LAGACHE, M. (1984): The exchange equilibrium distribution of alkali and alkaline-earth elements between feldspars and hydrothermal solutions. In Feldspars and Feldspathoids: Structure, Properties and Occurrences (W.L. Brown, ed.) NATO Adv. Study Inst., Ser. C 137. Reidel Publishing Co., Dordrecht, The Netherlands (247-279).

LASAGA, A.C. \& Blum, A.E. (1986): Surface chemistry, etch pits and mineral-water interactions. Geochim. Cosmochim. Acta 50, 2363-2379.

LAVES, F. (1960): The feldspars, their polysynthetic twinning and their phase relations. Rend. Soc. Mineral. Ital. 16, $37-100$.

Lee, M.R., Hodson, M.E. \& Parsons, I. (1998) The role of intragranular microtextures and microstructures in chemical and mechanical weathering: direct comparisons of experimentally and naturally weathered alkali feldspars. Geochim. Cosmochim. Acta 62, 2771-2788.

Lee, M.R. \& Parsons, I. (1995): Microtextural controls of weathering of perthitic alkali feldspars. Geochim. Cosmochim. Acta 59, 4465-4488.

LEE, M.R. \& PARSONS, I. (1997a): Dislocation formation and albitization in alkali feldspars from the Shap granite. Am. Mineral. 82, 557-570.

Lee, M.R. \& Parsons, I. (1997b): Compositional and microtextural zoning in alkali feldspars from the Shap granite and its geochemical implications. J. Geol. Soc. London 154, 183-188.

LeE, M.R. \& Parsons, I. (1998) Microtextural controls of diagenetic alteration of detrital alkali feldspars: a case study of the Shap conglomerate (Lower Carboniferous), north-west England. J. Sed. Res. 68, 198-211.

LeE, M.R. \& Parsons, I. (2003) Microtextures of authigenic Or-rich feldspar in the Upper Jurassic Humber Group, UK North Sea. Sedimentology 50, 597-608.

Lee, M.R., Thompson, P., Poeml, P. \& Parsons, I. (2003): Peristeritic plagioclase in North Sea hydrocarbon reservoir rocks: implications for diagenesis, provenance and stratigraphic correlation. Am. Mineral. 88, 866-875.

Lee, M.R., Waldron, K.A. \& Parsons, I. (1995): Exsolution and alteration microtextures in alkali feldspar phenocrysts from the Shap granite. Mineral. Mag. 59, 63-78.

Lehmann, G. (1984): Spectroscopy of feldspars. In Feldspars and Feldspathoids: Structure, Properties and Occurrences (W.L. Brown, ed.). NATO Adv. Study Inst., Ser. C 421. Reidel Publishing Co., Dordrecht, The Netherlands (121162). 
Lewis, C.L.E., Green, P.F., Carter, A. \& Hurford, A.J. (1992): Elevated K/T palaeotemperatures throughout northwest England: three kilometres of Tertiary erosion? Earth Planet. Sci. Lett. 112, 131-145.

MacKenzIE, W.S. (1957): The crystalline modifications of $\mathrm{NaAlSi}_{3} \mathrm{O}_{8}$. Am. J. Sci. 255, 481-516.

Martin, R.F. (1969): The hydrothermal synthesis of low albite. Contrib. Mineral. Petrol. 23, 323-339.

Mclaren, A.C. \& Fitz Gerald, J.D. (1987): CBED and ALCHEMI investigation of local symmetry and $\mathrm{Al}, \mathrm{Si}$ ordering in K-feldspars. Phys. Chem. Minerals 14, 281292

Milliken, K.L. (1989): Petrography and composition of authigenic feldspars, Oligocene Frio formation, south Texas. $J$. Sed. Petrol. 59, 361-374.

MüLLER, G. (1971): Der Einfluss der Al, Si-Verteilung auf die Mischungslücke der Alkalifeldspäte. Contrib. Mineral. Petrol. 34, 73-79.

MuRPHY, W.M. (1989): Dislocations and feldspar dissolution. Eur. J. Mineral. 1, 315-326.

Nyfeler, D., Armbruster, T. \& Villa, I.M. (1998): Si, Al, Fe order-disorder in Fe-bearing K-feldspar from Madagascar and its implications to Ar diffusion. Schweiz. Mineral. Petrogr. Mitt. 78, 11-21.

ORVILLE, P.M. (1963): Alkali ion exchange between vapor and feldspar phases. Am. J. Sci. 261, 210-237.

PARSONS, I. \& BROWN, W.L. (1984): Feldspars and the thermal history of igneous rocks. In Feldspars and Feldspathoids: Structure, Properties and Occurrences (W.L. Brown, ed.). NATO Adv. Study Inst., Ser. C 421. Reidel Publishing Co., Dordrecht, The Netherlands (317-371).

PARsons, I. \& Brown, W.L. \& SMith, J.V. (1999): ${ }^{40} \mathrm{Ar} /{ }^{39} \mathrm{Ar}$ thermochronology using alkali feldspars: real thermal history or mathematical mirage of microtexture? Contrib. Mineral. Petrol. 136, 92-110.

Parsons, I. \& Lee, M.R. \& Smith, J.V. (1998): Biochemical evolution. II. Origin of life in tubular microstructures on weathered feldspar surfaces. Proc. Nat. Acad. Sci. USA 95, 15173-15176.

Parsons, I., ReX, D.C., Guise, P. \& Halliday, A.N. (1988): Argon-loss by alkali feldspars. Geochim. Cosmochim. Acta 52, 1097-1112.

Parsons, I., Thompson, P., Lee, M.R. \& Cayzer, N. (2005): Alkali feldspar microtextures as provenance indicators in siliciclastic rocks and their role in feldspar dissolution during transport and diagenesis. J. Sed. Res. 75, 921-942.

Petrovic, R. (1976): Rate control in feldspar dissolution. II. The protective effect of precipitates. Geochim. Cosmochim. Acta 40, 1509-1521.

PRIESs, U. (1981): Untersuchungen zur Tief-Hoch-Umwandlung von Fe-haltingen Orthoklas-Kristallen aus Madagaskar. Neues Jahrb. Mineral., Abh. 141, 17-29.
Putnis, A. (2002): Mineral replacement reactions: from macroscopic observations to microscopic mechanisms. Mineral. Mag. 66, 689-708.

Scott, R.B., Bachinski, S.W., Nesbitt, R.W. \& Scott, M.R. (1971): Rate of Al-Si ordering in sanidines from an ignimbrite cooling unit. Am. Mineral. 56, 1208-1221.

Smith, J.V., Arnold, F.P., Parsons, I. \& LeE, M.R. (1999): Biochemical evolution. III. Polymerization on organophilic silica-rich surfaces; crystal chemical modeling; formation of the first cells; geological clues. Proc. Nat. Acad. Sci. USA 96, 3479-3485.

Smith, J.V. \& Brown, W.L. (1988): Feldspar Minerals 1 (2 ed.). Springer-Verlag, Berlin, Germany.

Smith, J.V. \& MacKenzie, W.S. (1958): Alkali feldspars IV. The cooling history of high-temperature sodium-rich feldspars. Am. Mineral. 43, 872-889.

SNOw, E. \& Yund, R.A. (1988): Origin of cryptoperthites in the Bishop Tuff and their bearing in its thermal history. $J$. Geophys. Res. 93, 8975-8984.

Spooner, N.A. (1994): The anomalous fading of infraredstimulated luminescence from feldspars. Radiation Measurements 23, 625-632.

Su, Shu-Chun, RibBe, P.H. \& Bloss, F.D. (1986): Alkali feldspars: structural state determined from composition and optic axial angle 2V. Am. Mineral. 71, 1285-1296.

Stewart, D.J. (1986): Diagenesis of the shallow marine Fulmar Formation of the central North Sea. Clay Minerals 21, 537-564

Teertstra, D.K., Hawthorne, F.C. \& Černý, P. (1998) Identification of normal and anomalous compositions of minerals by electron-microprobe analysis. Can. Mineral. 36, 87-95.

Teng, H.H., Fenter, P., Cheng, L. \& Sturchio, N.C. (2001): Resolving orthoclase dissolution processes with atomic force microscopy and X-ray reflectivity. Geochim. Cosmochim. Acta 65, 3459-3474.

Thompson, J.B., JR. (1969): Chemical reactions in crystals. Am. Mineral. 54, 341-375.

Velbel, M.A. (1989): Effect of chemical affinity on feldspar hydrolysis rates in two natural weathering systems. Chem. Geol. 78, 245-253.

VILLA, I.M. (1996): The influence of irradiation and heating schedule on Ar diffusion in gem-quality orthoclase from Madagascar. J. Conf. Abstr. 1(1), 652.

VisOcEKAS, R. \& ZinK, A. (1999): Use of the far infrared TL emission band of alkali feldspars for dosimetry and dating. Quaternary Sci. Rev. 18, 271-278.

Wadge, A.J., Gale, N.H., Beckinsale, R.D. \& Rundle, C.C. (1978): A Rb-Sr isochron for the Shap granite. Proc. Yorkshire Geol. Soc. 42, 297-305. 
Waldron, K.A., LeE, M.R. \& Parsons, I. (1994): The microstructure of perthitic alkali feldspars revealed by hydrofluoric acid etching. Contrib. Mineral. Petrol. 116, 360-364.

WALdRon, K.A., PARSONS, I. \& Brown, W.L. (1993): Solution-redeposition and the orthoclase-microcline transformation: evidence from granulites and relevance to ${ }^{18} \mathrm{O}$ exchange. Mineral. Mag. 57, 687-695.

WALKER, F.D.L., PARsons, I. \& Brown, W.L. (1995): Micropores and micropermeable texture in alkali feldspars: geochemical and geophysical implications. Mineral. Mag. $\mathbf{5 9}, 507-536$

Wartho, J.-A., Kelley, S.P., Brooker, R.A., Carroll, M.R., ViLLA, I.M. \& LeE, M.R. (1999): Direct measurement of Ar diffusion profiles in a gem-quality Madagascar Kfeldspar using the ultra-violet laser ablation microprobe (UVLAMP). Earth Planet. Sci. Lett. 170, 141-153.

WIDDER, W. (1991): Röntgentopographische Untersuchungen am Sanidin von Volkesfeld und Orthoklas von Madagaskar. Diplomarbeit an der Fakultät für Physik, Universität Karlsruhe, Karlsruhe, Germany.

Widder, W., Wondratschek, H., Fehlmann, M. \& KlapPer, H. (1994): X-ray topographic study of Eifel sanidine (Volkesfeld). Z. Kristallogr. 209, 206-209.

Wilkinson, M., Darby, D., Haszeldine, R.S. \& Couples, G.D. (1997): Secondary porosity generation during deep burial associated with overpressure leak-off: Fulmar Formation, United Kingdom Central Graben. Bull. Am. Assoc. Petrol. Geol. 81, 803-813.

WiLKinson, M. \& HASZELDine, R.S. (1996): Aluminium loss during sandstone diagenesis. J. Geol. Soc. London 153, 657-660.

Willaime, C. \& Brown, W.L. (1974): A coherent elastic model for the determination of the orientation of exsolution boundaries: application to the feldspars. Acta Crystallogr. A30, 316-331.

Willaime, C., Christie, J.M. \& Kovacs, M.-P. (1979): Experimental deformation of K-feldspar single crystals. Bull. Minéral. 102, 167-177.

Willaime, C. \& Gandais, M. (1977): Electron microscope study of plastic defects in experimentally deformed alkali feldspars. Bull. Soc. fr. Minéral. Cristallogr. 100, 263 271.

WiLSON, M.J. (1975): Chemical weathering of some primary rock-forming minerals. Soil. Sci. 119, 349-355.

WintLE, A.G. (1973): Anomalous fading of TL in mineral samples. Nature 245, 143-144.

WORDEN, R.H. \& RUSHTON, J.C. (1992): Diagenetic K-feldspar textures: a TEM study and model for diagenetic feldspar growth. J. Sed. Petrol. 62, 779-789.

Worden, R.H., Walker, F.D.L., Parsons, I. \& Brown, W.L. (1990): Development of microporosity, diffusion channels and deuteric coarsening in perthitic alkali feldspars. Contrib. Mineral. Petrol. 104, 507-515.

Yund, R.A. (1974): Coherent exsolution in the alkali feldspars. In Geochemical Transport and Kinetics (A.W. Hofmann et al., eds.). Carnegie Institution Washington and Academic Press, New York, N.Y. (173-183).

YunD, R.A. (1984): Alkali feldspar exsolution: kinetics and dependence on alkali interdiffusion. In Feldspars and Feldspathoids: Structure, Properties and Occurrences (W.L. Brown, ed.). NATO Adv. Study Inst., Ser. C 137. Reidel Publishing Co., Dordrecht, The Netherlands (281-315).

Yund, R.A. \& Chapple, W.M. (1980): Thermal histories of two lava flows estimated from cryptoperthite lamellar spacings. Am. Mineral. 65, 438-443.

Yund, R.A. \& DAVIDSON, P. (1978): Kinetics of lamellar coarsening in cryptoperthites. Am. Mineral. 63, 470-477.

ZEIPERT, C. \& WONDRATSCHEK, H. (1981): An unusual annealing behaviour of Eifel sanidine. Neues Jahrb. Mineral., Monatsh., 407-415.

Zeitler, P.K., Chamberlain, C.P. \& Smith, H.A. (1993): Synchronous anatexis, metamorphism, and rapid denudation at Nanga Parbat (Pakistan Himalaya). Geology 21, 347-350.

ZiNK, A., VISOCEKAS, R. \& Bos, A.J.J. (1995): Comparison of blue and infrared-emission bands in thermoluminesence of alkali feldspars. Radiation Measurements 24, 513-518.

Received June 15, 2005, revised manuscript received December 15,2005 . 